\title{
Engineering of Live Chimeric Vaccines against Human Metapneumovirus
}

\author{
Daniela Ogonczyk Makowska $₫$, Marie-Ève Hamelin and Guy Boivin * \\ Centre de Recherche en Infectiologie of the Centre Hospitalier Universitaire de Québec and Université Laval, \\ Québec, QC G1V 4G2, Canada; daniela.ogonczyk-makowska@crchudequebec.ulaval.ca (D.O.M.); \\ marie-eve.hamelin@crchudequebec.ulaval.ca (M.-È.H.) \\ * Correspondence: guy.boivin@crchudequebec.ulaval.ca
}

Received: 29 November 2019; Accepted: 14 February 2020; Published: 19 February 2020

check for updates

\begin{abstract}
Human metapneumovirus (HMPV) is an important human pathogen that, along with respiratory syncytial virus (RSV), is a major cause of respiratory tract infections in young infants. Development of an effective vaccine against Pneumoviruses has proven to be particularly difficult; despite over 50 years of research in this field, no vaccine against HMPV or RSV is currently available. Recombinant chimeric viruses expressing antigens of other viruses can be generated by reverse genetics and used for simultaneous immunization against more than one pathogen. This approach can result in the development of promising vaccine candidates against HMPV, and several studies have indeed validated viral vectors expressing HMPV antigens. In this review, we summarize current efforts in generating recombinant chimeric vaccines against HMPV, and we discuss their potential optimization based on the correspondence with RSV studies.
\end{abstract}

Keywords: human metapneumovirus; respiratory syncytial virus; chimeric vaccines; recombinant vaccines; viral vectors; bivalent vaccines

\section{Introduction}

Acute respiratory tract infections (RTIs) are the $5^{\text {th }}$ leading global cause of mortality among all age groups and the $3^{\text {rd }}$ leading mortality cause in children younger than 5 years old [1]. An important number of RTIs is caused by viruses belonging to the Pneumoviridae family, namely, respiratory syncytial virus (RSV) and human metapneumovirus (HMPV) that are responsible for approximately $31 \%$ and $5.5 \%$ of RTIs in children, respectively [2].

HMPV is a single-stranded, negative-sense RNA virus belonging to the family of Pneumoviridae, genus Metapneumovirus. The genus has two species: human and avian metapneumovirus (AMPV). HMPVs are divided into two major genetic subtypes: $\mathrm{A}$ and $\mathrm{B}$ that are further divided into sublineages $\mathrm{A} 1, \mathrm{~A} 2 \mathrm{a}$, A2b, B1, and B2 [3]. Lineages A and B share $80 \%$ and $90 \%$ of their nucleotide and amino acid sequence identity, correspondingly [4]. The major antigen of HMPV, the F protein, is highly conserved and a high level of cross-neutralization and cross-protection is observed between the two lineages [5,6]. The clinical signs of HMPV disease do not vary significantly between the different genetic lineages of HMPV [7]. AMPV, previously known as turkey rhinotracheitis virus, is an important poultry pathogen, divided into subgroups A, B, C, and D [8-10]. The subgroup C (AMPV_C) shares $80 \%$ of the amino acid identity of N, P, M, F, M2-1, and M2-2 proteins with HMPV [11], making it the closest related virus to HMPV.

HMPV is a relatively newly-discovered pathogen, described for the first time by the researchers from the Netherlands in 2001 [11]. Its late identification can be explained by the similarity of symptoms caused by HMPV and RSV, as well as the difficulty to observe HMPV growth in vitro. Both viruses cause pneumonia and bronchiolitis, with variable severity of illness according to age [12]. Although HMPV disease is generally less severe compared to RSV, the incidence of infections caused by HMPV 
is similar to that of influenza and parainfluenza, and it causes a significant number of hospitalizations every year [13]. Infections with either virus are associated with the development of asthma and its exacerbations, yet the causal relationship has not been established [2,14,15]. Although both pneumoviruses can infect any age group, they cause the greatest disease severity in young infants. HMPV infects mainly children between 6 and 12 months of age, whereas RSV infects infants earlier, within the first 2-3 months after the birth [2,16-19]. Virtually every child is infected by RSV by the age of 2 [20] and by HMPV by the age of 5 [21], and the incidence of reinfections with both viruses increases significantly after the age of 50 causing a lot of RTIs in elderly [19,22]. Another population at risk of HMPV infections is comprised of immunosuppressed patients [23].

\subsection{Need for a Vaccine}

Despite the high frequency of pneumoviral infections and over 50 years of research in this field, no licensed vaccine against HMPV or RSV is currently available. Among the numerous vaccine candidates against RSV that have been developed, only a few have advanced to clinical trials and most of them failed as a result of insufficient immunogenicity or underattenuation [24]. The only anti-HMPV vaccine advanced to clinical trials until now-a live-attenuated recombinant $r H M P V-P_{A}$ virus, in which HMPV-P protein was exchanged for its counterpart from AMPV_C_-proved to be insufficiently immunogenic and overattenuated in seronegative children, thus leaving no advanced candidates for an anti-HMPV vaccine [25].

This lack of effective vaccine candidates against HMPV can be explained by the recent discovery of the virus, but also by the lack of a successful vaccine against closely related RSV that could serve as a base for vaccine design. One of the reasons for the slow progress in this field is the clinical failure of formalin-inactivated RSV-vaccine (FI-RSV) that occurred in the 1960s. The administration of FI-RSV led to the development of an exaggerated immune response to wild type (wt) RSV infection with enhanced pulmonary disease (EPD) and two vaccinated children died [26]. EPD has been further documented in various animal models, indicating that it is not only a human phenomenon [27-30]. A similar effect was observed for a formalin or heat-inactivated HMPV vaccine, which induced the symptoms of EPD in rodents [31,32]. Another reason for slow vaccine development is the transient immunity provided by natural infection with RSV and HMPV. As documented in RSV-seropositive adults, levels of RSV-neutralizing antibodies correlate with the resistance to subsequent RSV infection, but the protection they confer is incomplete and short-lasting, which results in frequent reinfections $[20,33]$. The immune response to primary HMPV infection was described to be weak and aberrant in BALB/c mice, with excessive Th2-cytokines production at later stages of infection, which correlated with airways hyperresponsiveness and the development of asthma [34]. Pneumoviruses have also developed many mechanisms to evade immune responses. The RSV nonstructural proteins NS1 and NS2 suppress the IFN-induced antiviral response in infected cells and removal of these proteins resulted in the induction of high levels of IFN alpha and beta in vitro [35-37]. HMPV shares with RSV the same ability to decrease IFN response, despite the lack of NS1 and NS2 proteins. It has been documented that HMPV-G protein has the ability to inhibit the IFN type 1 response in vitro and in vivo $[38,39]$ and that its SH and M2-2 proteins can also modulate the host's immune responses [40-42]. Both HMPV and RSV can persist in the lungs of an infected animal host, despite the presence of neutralizing antibodies [34,43]. Such persistence has been documented by RT-PCR detection of viral RNA in the guinea pig and mouse models for RSV [44-46] and in mice for HMPV [43]. Another hurdle to effective immunization is the presence of maternal antibodies in the bloodstream of vaccinated infants that can impair the immunogenic effect of the vaccine [47], yet the role of maternal antibodies in RSV infection is not fully understood [48].

\subsection{Vaccine Development}

The main objectives in pneumovirus vaccine development are to avoid EPD and obtain sufficient immunogenicity without causing disease. Viral protein antigens can be used as subunit vaccines to 
induce an appropriate immune response. These proteins can be delivered as nanoparticles, virus-like particles (VLPs), or they can be coupled with adjuvants [49]. Another interesting strategy is to immunize with viral nucleic acid coding for viral antigens, as it has been documented for RSV and HMPV vaccine candidates [50-52]. An mRNA-based vaccine coding for the F proteins of HMPV and human parainfluenza type 3 virus (PIV3) has been recently advanced to phase 1 clinical trial [53].

Among the three surface proteins of $\mathrm{HMPV}(\mathrm{F}, \mathrm{G}$, and $\mathrm{SH})$, the F protein constitutes the major HMPV antigen $[6,54,55]$. Although immunogenic, its $G$ protein does not induce a potent protective immune response [54,56] and is not indispensable for viral replication in vivo [57]. HMPV-SH protein was shown not to confer any significant protection [54], the same being observed for RSV [58]. The F protein is also the major antigen of RSV, more immunogenic than the G protein [59], although the latter is also able to induce a protective immune response $[60,61]$ and has been frequently tested as a subunit vaccine [62-64]. RSV-F protein stabilized in its pre-fusion form by introducing disulfide bond (DS) and cavity-filling (Cav1) mutations (DS-Cav1) is currently being tested as a subunit vaccine in phase I clinical trials (ClinicalTrials.gov Identifier: NCT03049488). The pre-fusion RSV-F was shown to be more immunogenic than its postfusion conformation, as a result of an exposition of a unique antigenic site $\varnothing$ that is recognized by very potent RSV-neutralizing antibodies [65-67]. Trials with the HMPV-F subunit vaccine showed that the vaccine was immunogenic, but not protective in a rodent model [68]. To increase its immunogenic potential, HMPV-F protein has been stabilized in its pre-fusion state by analogous strategies as for RSV-F, but its immunogenicity was not enhanced $[69,70]$. This difference between pre-fusion RSV-F and HMPV-F can be explained by additional glycosylation at the apex of the pre-fusion form of HMPV-F. HMPV-F and RSV-F share some antigenic sites, and antibodies able to cross-neutralize the two pneumoviruses were identified [71-75]. Grafting of a major protective epitope from RSV-F into HMPV-F protein resulted in the elaboration of a chimeric protein carrying epitopes of both pneumoviruses, an interesting candidate for vaccine design [76,77].

Several promising nanoparticle vaccines against RSV have been elaborated [78,79], among which is ResVax, a nanoparticle RSV-F-based vaccine developed by Novavax [80]. ResVax has been recently tested in phase 3 clinical trials in maternal immunization model of lower RTIs prevention in infants (NCT02624947), where it did not meet its clinical endpoint [81]. VLPs are structures composed of the proteins of viral capsid; they do not contain the viral genome and are replication-incompetent. Coexpression of HMPV-F, -G, and -M proteins leads to the formation of VLPs in vitro [82], yet the expression of only $\mathrm{F}$ and $\mathrm{M}$ proteins has been shown sufficient for VLPs assembly [83]. Several potential VLPs vaccines against HMPV [82-85], and many more against RSV [78,86-105], were developed, but none of them has been advanced to clinical trials. A promising vaccine candidate-a VLP composed of pre-fusion, postfusion RSV-F, or both together, assembled with HMPV-M protein-conferred full protection against RSV infection in immunized mice [96].

On the other hand, immunization with an attenuated replication-competent virus is a very promising approach. In this case, it is possible to obtain a vaccine that presents all viral epitopes and is able to induce both humoral and cellular immune responses [106]. The main disadvantage of live attenuated vaccines is the risk of reversion of the attenuated profile, restoration of infectivity and subsequent development of the disease [107]. Live attenuated viruses can be divided into two groups: non-recombinant and recombinant or chimeric viruses. Non-recombinant viruses are rendered less infectious due to genetic modifications that appear naturally during serial passages in vitro in conditions of environmental stress. Several attenuated strains of RSV and HMPV have been obtained as a result of serial cold passages or chemical mutagenesis, which confer a temperature-sensitive $(t s)$ phenotype to a virus [108-112]. Apart from the mentioned selection strategy, recombinant attenuated viruses can be generated by reverse genetics, a technique that makes it possible to generate functional particles of a modified virus based on its genetic material $[113,114]$. This approach allows not only to introduce attenuating mutations directly into the viral genome $[57,115]$, but also to express exogenous antigens in the backbone of the virus, leading to the development of polyvalent, chimeric vaccines. The insertion of a foreign gene can have a potentially attenuating effect on its own, for 
example, by rearranging the order of genes in terms of $3^{\prime}-5^{\prime}$ expression gradient, as it is observed in paramyxoviruses. Gene order can also be changed in a more invasive way by moving virulence genes from the high-expression position to the low-expression locus. Alternatively, the replication efficiency can be decreased by deletions or silencing of nonessential viral proteins that play an accessory function in the life cycle of the virus. It is also possible to swap some of the genes between strains of different host preferences, thus introducing new host range restrictions. HMPV virus with the $P$ gene exchanged for its AMPV_C counterpart (rHMPV- $\left.\mathrm{P}_{\mathrm{A}}\right)$ was more attenuated than wt HMPV, and yet protective against HMPV infection in African green monkeys (AGMs) [116]. In this review, we will focus on and discuss in detail the development of live recombinant vaccines against HMPV.

\subsection{Target Populations}

The ultimate goal of HMPV vaccination is the prevention of lower RTIs in populations at risk. Similarly to RSV, the target populations for HMPV vaccination are young children, elderly people, and pregnant women [117]. Early vaccination of infants and young children can potentially prevent HMPV-infections and the transmission of the virus. Replication-competent vaccines, namely, live-attenuated HMPV or recombinant viruses are a good choice for this population. Another vaccine strategy, prime-boost regimen, consists of vaccinating with gene-based/live vaccine first and then with a protein/particle-based vaccine [118]. Immunization of pregnant women can not only provide a passive antibody transfer to their children but also prevent a mother-to-child transmission of HMPV. Live vaccines are considered being too risky to be used in this population; therefore, subunit vaccines or VLPs with standard adjuvants should be considered. The effect of vaccination of adult populations with live vaccines can be hampered by the presence of anti-HMPV antibodies in the bloodstream or in the respiratory tract (RT). For the vaccination of elderly people, who had experienced multiple HMPV infections, subunit or VLPs with a potent adjuvant are recommended [118].

\section{Vector-Based Chimeric Vaccines}

One of the strategies aimed to circumvent the problem of incomplete immunity provided by natural HMPV infection is to express its protective antigens in the backbone of a more immunogenic virus. The increase in immunogenicity can also be provided by improved antigen expression by the vector, as demonstrated for a recombinant bovine/human PIV3 (rB/HPIV3) expressing either RSV-F or G proteins [60] and for human parainfluenza type 1 virus (HPIV1) expressing HMPV antigens [54]. HMPV is difficult to grow in cell culture; vectoring its antigens with the backbone of a better-replicating virus can facilitate vaccine development and manufacturing. For instance, rB/HPIV3 expressing RSV-F reaches 10-100-fold higher viral titers in vivo compared to wt RSV [60] and replicates more efficiently in the RT of AGMs than wt RSV or HMPV $[119,120]$. Expression of a foreign antigen in the backbone of another virus can also mitigate the problem of pre-existing immunity that often diminishes the effect of the vaccine. Using vectors of another host range can facilitate the immunization of seropositive individuals with no risk of causing disease, as it has been described for Newcastle Disease Virus (NDV) expressing RSV-F. The majority of live vaccines against RSV and HMPV up to date have been attenuated by a few codon changes in their genome. Therefore, using more stably attenuated backbone can render the attenuation more reliable, and decrease the risk of the reversion of an attenuated phenotype. The insertion of an additional gene can itself influence the virus' replicative capacity, thus limiting its ability to spread and cause the disease, but also to create the risk of overattenuation. This subtle balance between attenuation and immunogenicity remains the major challenge of vaccine development.

In general, vector-based chimeric vaccines retain the advantages of live attenuated vaccines and they can be readily generated by reverse genetics. Most of the backbones used so far for vectoring pneumoviral antigens belong to the Paramyxoviridae family. These viruses are closely related, both phylogenetically and structurally, to pneumoviruses. This close relationship increases the chance of an efficient expression and integration of a pneumoviral protein in the background of a paramyxoviral vector. Among paramyxoviruses, the most widely used vaccine backbones are bovine parainfluenza 
virus type 3 (BPIV3) and its recombinant derivative rB/HPIV3, HPIV1, parainfluenza virus type 5 (PIV5), Newcastle Disease Virus (NDV), and Sendai virus (SeV). The reasons explaining this frequent use of paramyxoviruses as vaccine backbones are numerous: First, their genomes are well-characterized and complete genomic sequences of all known members of this family are easily accessible [121]. Second, their genomes are simple and organized in a modular way. Tandem alignment of the genes, of which the most are transcribed as separate mRNA products, facilitates genetic manipulations [122]. Third, most paramyxoviruses are able to replicate efficiently in cell lines certified for vaccine manufacture, such as Vero cells, which can facilitate vaccine development [122]. Fourth, as they replicate entirely in the cytoplasm and their replication cycle does not involve the integration into the host cell genome, their use is potentially safe [121]. Also, recombination events between mononegaviruses have not been observed in nature and they remain extremely rare in vitro, even in optimized conditions [123,124], indicating that there is a low probability of gene exchange between engineered vaccine viruses and the pathogens present in the environment. Fifth, the small probability of recombination also contributes to the stability of a genetic insert, providing a stable foreign gene expression system. Paramyxoviruses are able to stably express several exogenes simultaneously and the level of expression can be manipulated by changing the position of gene insertion [125]. Sixth, most paramyxoviruses infect their host via their $\mathrm{RT}$, representing an easy and safe route of administration of the vaccine as well as for induction of both local and systemic immune responses. Last, but not least, there are many animal paramyxoviruses that are naturally attenuated in humans due to a host range restriction. Mutations that render these viruses harmless to people have been identified and characterized, thus making attenuation of different paramyxoviruses possible [122].

\section{Recombinant Virus Engineering}

\subsection{Reverse Genetics}

Negative strand viruses can be readily recovered from cell cultures by means of reverse genetics [126]. This technique makes it possible to engineer a fully functional virus starting from its genetic sequence. The genetic material in the form of cDNA can be easily modified according to the vaccine design. The technique is based on transfecting permissive cells with a plasmid coding for the viral genome and satellite plasmids coding for all the proteins necessary for the formation of a ribonucleoprotein complex (RNP) that initiates the transcription of viral genes (Figure 1). The proteins indispensable to form the RNP in paramyxoviruses and pneumoviruses are N, P, and L proteins [127-129], yet the addition of M2-1 protein facilitates the recovery HMPV from cDNA [130]. The elaboration of a polyvalent vaccine can be accomplished by either cloning additional genes into the plasmid coding for viral genome or replacing protective antigens of a vector with the ones of another pathogen.

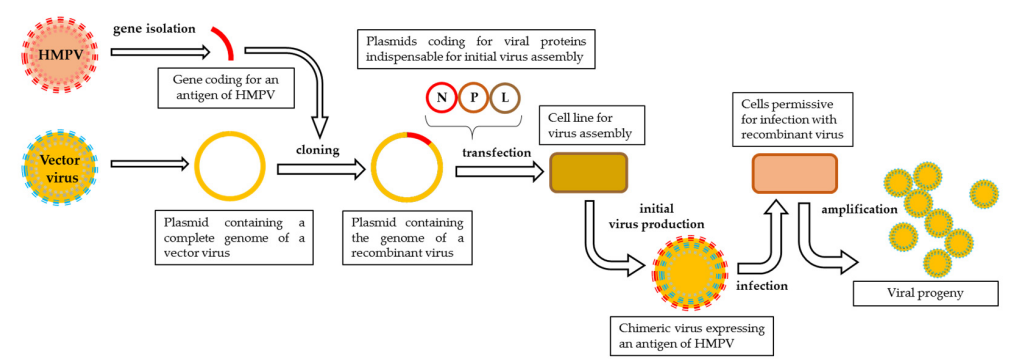

Figure 1. Schematic representation of reverse genetics pipeline. The exogene of interest is cloned into a plasmid containing a complete genome of a vector virus and then transfected, along with satellite plasmids coding for viral proteins indispensable to initiate viral assembly, into a cell line designed for initial virus production. The first progeny of the recombinant virus is harvested and propagated on a permissive cell line. 


\subsection{Genomic Organization of Paramyxoviridae and Pneumoviridae}

The genomes of Paramyxoviridae and Pneumoviridae consist of a simple, nonsegmented, linear, single-stranded, 15,000-19,000-nucleotide-long negative RNA that contains 6-10 genes [121]. The most 3'-proximal region consists of a leader (le) —a 50-nucleotide-long promoter-and each gene is preceded and followed by a short (10-13 nucleotides) conserved sequence named gene start (GS) and gene end (GE). These sequences act like transcription control signals for viral RNA-dependent RNA-polymerase (vRNAP) and they guide the enzyme along the genome [131]. Single genes are separated from each other by short, non-coding intergenic regions and the order of the genes is usually conserved as 3'-Nucleoprotein (N), Phosphoprotein (P), Matrix Protein (M), Glycoprotein $(\mathrm{G})$, Hemagglutinin-Neuraminidase $(\mathrm{HN})$, or Large Polymerase subunit $(\mathrm{L})-5^{\prime}$ with the presence and location of additional genes depending on the virus [132] (Figure 2).

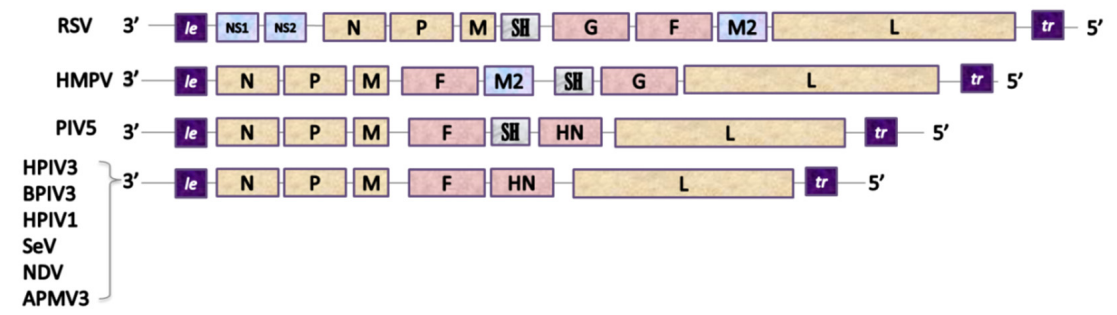

Figure 2. Genetic organization of Pneumoviruses and some of Paramyxoviruses used as viral vectors. Pneumoviridae: RSV: Respiratory Syncytial Virus (Orthopneumovirus), HMPV: Human Metapneumovirus (Metapneumovirus). Paramyxoviridae: PIV5: Parainfluenza type 5 virus (Rubulavirus), HPIV3: Human Parainfluenza type 3 virus, BPIV3: Bovine Parainfluenza type 3 virus, HPIV1: Human Parainfluenza type 1 virus and SeV: Sendai Virus (Respirovirus), NDV: Newcastle Disease Virus and APMV3: Avian Paramyxovirus type 3 (Avulavirus). Genes: le: leader, NS1 and NS2: accessory proteins of RSV, N: nucleoprotein, P: phosphoprotein, M: matrix protein, F: fusion protein, SH: small hydrophobic protein, G: attachment glycoprotein, HN: Haemagglutinin-Neuraminidase protein, M2: gene coding for M2-1 and M2-2 proteins, L: large polymerase subunit.

The 5 '-end of a genome contains a trailer sequence ( $t r$ ) of a variable length, ranging from 50 up to 707 nucleotides [121,133]. The genomic RNA of paramyxoviruses and pneumoviruses does not exist as an unbound RNA-particle: it is always assembled with numerous copies of $\mathrm{N}$ protein and forms a helicoidal nucleocapsid. In paramyxoviruses, each $\mathrm{N}$ protein molecule is associated with precisely six nucleotides, a feature that is believed to underlay the "rule of six", i.e., the length of the genome of paramyxoviruses has to be a multiple of six for an effective viral replication [134,135]. The stringent adhesion to this rule is observed for SeV [136]; for other viruses, like PIV5, NDV, and HPIV3, it strongly increases the efficacy of replication [137-139]. The fact that it does not give any replicative advantage to RSV [140] might be explained by distinct differences in nucleocapsid structure of the two families [141]. Transcription of the viral genome is initiated at the 3'-end and a 3'-to 5' expression gradient is observed. The complex of vRNAP sporadically fails to resume the synthesis of another distinct mRNA at each gene junction, which results in a gradual loss of transcription-efficacy along the genome [121].

\subsection{Principles of Exogene Insertions}

The main principles to be taken into consideration while engineering the genome of recombinant paramyxoviruses are the preferential adherence to the rule of six, a coherence of transcription control signals (GS/GE) used to drive the expression of a foreign antigen and exogene positioning in the transcription gradient. As it has been documented in numerous studies, the GS and GE signals of the vector virus can efficiently direct the expression of an exogenous protein [60]. Although GS and GE signals are often highly conserved along the viral genome, there might be variations in their sequences and transcription efficacy [142]. Flanking the sequence of GFP inserted into the $6^{\text {th }}$ genome position of PIV5 with GS/GE specific for either $2^{\text {nd }}$ or $7^{\text {th }}$ gene junctions resulted in large differences in GFP 
expression levels (Figure 3) [143]. GS/GE characteristics for the $1^{\text {st }}$ junction provided better expression levels than the ones originating from the $7^{\text {th }}$. It is therefore important to flank the exogene with potent transcription regulators. In accordance with the $3^{\prime}-5^{\prime}$ transcription gradient, exogenes placed in more $3^{\prime}$-proximal position should be expressed better than $5^{\prime}$-proximal inserts, yet the tendency cannot be described as linear and some deviations are observed [144]. The adherence to this gradient might also be influenced by the type of attenuation of vector virus, as it has been demonstrated for HPIV1 bearing RSV-F protein [145]. The positions of an exogene in the viral genome are described in Figure 3 and the nomenclature used to label chimeric viruses in this review is explained in Figure 4.

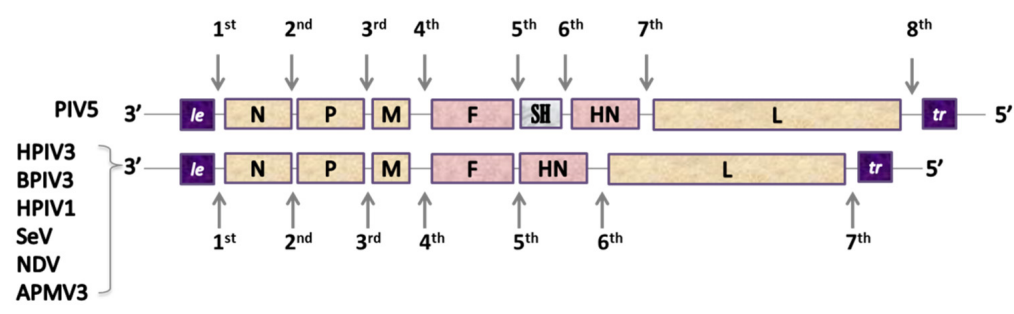

Figure 3. Insert-positions in the paramyxovirus genomes.

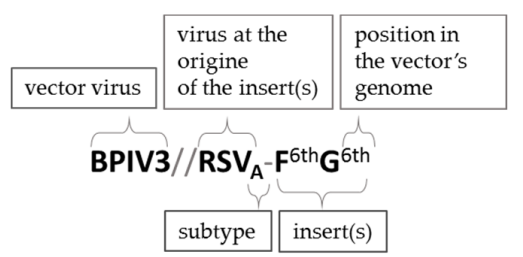

Figure 4. The nomenclature used in this review to describe chimeric viruses expressing additional antigens. The inserts are marked according to their 3'-5' order of the vector's genome. The subtype of the virus at the origin of the insert is marked if it is specified in the source. Although discussing different chimeric viruses based on the same vector that are mentioned in the same study, recombinant viruses can be also referred to as $\mathrm{F}^{1 \text { st }}, \mathrm{G}^{2 \text { nd }}$, etc. constructs. The nomenclature of vector backbones modified by additional mutations, protein swapping, etc. (i.e., $\mathrm{rHPIV}-\mathrm{C}^{\Delta 170}, \mathrm{rHMPV}_{\mathrm{A}}$ ) was unchanged in relation to the source publication.

On one hand, a 3'-proximal insertion should provide the best level of expression; on the other hand, it can influence the level of transcription of all downstream genes, leading to a decrease in viral replication. RSV-F insertion into $1^{\text {st }}$ position of $\mathrm{rB} / \mathrm{HPIV} 3$ genome reduced the expression of downstream genes by $20-45 \%$ [146]; $2^{\text {nd }}$ genomic position can provide a good expression, but it can also influence the N:P protein ratio, which plays a decisive role in the replicative capacity of paramyxoviruses, causing an additional attenuating effect [146]. Insertions in either $1^{\text {st }}$ or $2^{\text {nd }}$ genomic positions are the most privileged for PIV3-based vectors, with the $2^{\text {nd }}$ position usually providing better virus recovery, higher viral replication, and better exogene expression [147]. For some vectors, namely, NDV and Avian paramyxovirus serotype 3 (APMV3), the $3^{\text {rd }}$ position is the most advantageous, whereas the insertion at the $2^{\text {nd }}$ one results in delayed viral replication and the largest reduction in virus recovery [148-150]. The $4^{\text {th }}$ and the $5^{\text {th }}$ positions are not frequently used, so as to not influence the expression of vector's surface proteins ( $\mathrm{F}$ and $\mathrm{HN}$ ) [146], with the exception of studies on SeV bearing either RSV-F or HMPV-F at the $5^{\text {th }}$ position [151-153].

The nature of the insert itself can also influence the vector's biology. The rB/HPIV3//RSV-F ${ }^{1 s t}$ virus showed an 8-fold reduced replication in vitro compared to rB/HPIV3, whereas the RSV-G ${ }^{1 s t}$ insert did not influence viral replication [60]. This decrease in viral growth might have been due to excessive syncytia formation and increased cytopathology resulting from the expression of a second fusion protein. Another reason might have been the size of the insert-a bigger F protein might have influenced the replication more significantly than a smaller $G$ protein. The size of an exogene can significantly change the replicative capacity of the virus, as it has been shown for HPIV3 vector bearing 
inserts of different sizes [154]. The level of integration of a foreign protein into a vector's particle can also be a price to pay in the exchange for efficient expression of the exogene, as described in Chapter 5 of this review. Improved exogene integration into the vector's backbone can be obtained by the substitution of the transmembrane domain (TM) and cytoplasmic tail (CT) of the inserts with their equivalents from the vector virus. As demonstrated for HPIV1 vector bearing RSV-F protein either in its wt or chimeric TMCT form, packaging of RSV-F ${ }^{(\mathrm{TMCT})}$ was strongly improved, but the chimeric virus was overattenuated and not protective in hamsters [155].

\section{Examples of Chimeric Anti-HMPV Vaccines}

\subsection{Recombinant Bovine/Human Parainfluenza Type 3}

Replacing the F and HN genes of BPIV3 by their HPIV3 counterparts resulted in the elaboration of $\mathrm{rB} / \mathrm{HPIV} 3$, a recombinant virus broadly used for expressing foreign antigens. The virus is more immunogenic in humans than BPIV3 while retaining its attenuation profile [156]. Its safety and immunogenicity have been documented in adults, HPIV3-seropositive, and HPIV3-seronegative children [157]. rB/HPIV3 reaches 10-100-fold higher titers in vivo than RSV, which makes it a good platform for the studies on anti-pneumoviral vaccines [60]. PIV3 genome is approximately $15 \mathrm{~kb}$ in length and includes six structural genes [121]. Both HPIV3 and BPIV3 adhere to the "rule of six"; several viruses that were recovered from genome cDNA whose length did not fulfill this condition were found to have accommodated nucleotide insertions correcting their genome length [125].

rB/HPIV3 was broadly used to express RSV or HMPV antigens and the examples of rB/HPIV3-based vaccines that were tested in preclinical trials are shown in Table 1. Many different positions were tested for RSV-F insertion and a 30-69-fold gradual decrease in exogene expression was observed between the $1^{\text {st }}$ and the $6^{\text {th }}$ one [146]. Although 2-3 times more attenuating than the $3^{\text {rd }}$ or $6^{\text {th }}$ position, the $2^{\text {nd }}$ one provides a very attractive attenuation/exogene expression ratio. $\mathrm{rB} / \mathrm{HPIV} 3$ virus bearing RSV-F in the $2^{\text {nd }}$ position (MEDI-534) developed by MedImmune was tested in phase $1 / 2$ clinical trials (NCT00686075), but it was proven insufficiently immunogenic [158-160]. rB/HPIV3 can accommodate an insert of both RSV-F and G proteins in the $1^{\text {st }}$ position with little decrease in replication in vitro [61]. The same double insert placed in the $5^{\text {th }}$ position resulted in a ts phenotype and restricted replication in vivo, yet the virus was immunogenic and protective in hamsters [161].

The insertion of HMPV-F gene into either $1^{\text {st }}$ and $2^{\text {nd }}$ positions of $\mathrm{rB} / \mathrm{HPIV} 3$ genome resulted in efficient exogene expression as integral membrane proteins [147]. HMPV-F ${ }^{1 s t}$ chimeras were more difficult to recover and replicated less efficiently, and the same was observed for RSV-F inserts. The viruses were immunogenic and protective in hamsters and the HMPV-F ${ }^{2 n d}$ virus was subsequently evaluated as a vaccine in African green monkeys (AGMs) [120]. The virus replicated better than wt HMPV and it was protective against wt HMPV challenge. rB/HPIV3//HMPV-F ${ }^{2 n d}$ induced effective anti-HMPV-specific T-cell responses, that were slightly lower compared to wt HMPV. The levels of antibodies induced by the chimeric virus correlated with those that provided protection against lower respiratory tract (LRT) infections in primates [162] and infants [163]. 
Table 1. Examples of BPIV3-based vaccines against either RSV or HMPV with their immunogenicity and protection in animal models.

\begin{tabular}{|c|c|c|c|c|c|c|c|c|c|}
\hline \multicolumn{2}{|c|}{ Chimeric Vaccine } & \multicolumn{2}{|c|}{ Immunization } & \multicolumn{2}{|c|}{$\begin{array}{c}\text { Increase in Serum Antibody Titers Post } \\
\text { Immunization }\end{array}$} & \multirow[t]{2}{*}{ Challenge } & \multicolumn{2}{|c|}{$\begin{array}{c}\text { Challenge Virus Titers in RT } \\
{\left[\log _{10} \mathrm{PFU} / \mathrm{g} \pm \mathrm{SE}\right]}\end{array}$} & \multirow[t]{2}{*}{ Reference } \\
\hline Vector & Insert & Animal Model & Dose & Virus $^{\mathrm{A}}$-Neutralizing ${ }^{\mathrm{B}}$ & IgG ELISA Titers ${ }^{c}$ & & URT & LRT & \\
\hline \multirow{13}{*}{ rB/HPIV3 } & RSV-F ${ }^{1 s t}$ & \multirow{2}{*}{ hamsters } & \multirow{2}{*}{$1 \times 10^{6} \mathrm{TCID}_{50}$} & $9.3 \pm 0.5,26 \mathrm{dpi}$ & $9.4,26 \mathrm{dpi}$ & \multirow{2}{*}{$1 \times 10^{6} \mathrm{PFU}$ of RSV, $28 \mathrm{dpi}$} & $2.9 \pm 0.4,5 \mathrm{dpc}$ & $2.1 \pm 0.2,5 \mathrm{dpc}$ & \multirow{2}{*}{ [62] } \\
\hline & RSV-G ${ }^{1 s t}$ & & & $10.0 \pm 0.3,26 \mathrm{dpi}$ & $6.5,26 \mathrm{dpi}$ & & $1.9 \pm 0.2,5 \mathrm{dpc}$ & $\leq 1.7,5 \mathrm{dpc}$ & \\
\hline & $\mathrm{RSV}_{\mathrm{A}}-\mathrm{F}^{1 \mathrm{st}}$ & \multirow{7}{*}{ Rhesus macaques } & \multirow{7}{*}{$2^{\mathrm{D}} \times 10^{5} \mathrm{TCID}_{50}$} & $7.3 \pm 0.0,27 \mathrm{dpi}$ & $8.0,27 \mathrm{dpi}$ & \multirow{7}{*}{\multicolumn{2}{|c|}{ No challenge was performed }} & & \multirow{7}{*}[63]{} \\
\hline & $\mathrm{RSV}_{\mathrm{A}}-\mathrm{G}^{1 \mathrm{st}}$ & & & $7.3 \pm 1.4,27 \mathrm{dpi}$ & $5.5,27 \mathrm{dpi}$ & & & & \\
\hline & $\operatorname{RSV}_{A^{-}}-F^{1 s t} G^{1 s t}$ & & & $8.8 \pm 1.0,27 \mathrm{dpi}$ & $\begin{array}{c}8.0 \text { (anti-F), } \\
5.5 \text { (anti-G), } 27 \text { dpi }\end{array}$ & & & & \\
\hline & $\begin{array}{l}\mathrm{RSV}_{\mathrm{A}}-\mathrm{F}^{1 \mathrm{st}}+\mathrm{H} \\
\mathrm{RSV}_{\mathrm{A}}-\mathrm{G}^{1 \mathrm{st}}\end{array}$ & & & $7.3 \pm 0.8,27 \mathrm{dpi}$ & $\begin{array}{c}5.5 \text { (anti-F), } \\
5.5 \text { (anti-G), } 27 \text { dpi }\end{array}$ & & & & \\
\hline & $\mathrm{RSV}_{\mathrm{B}}-\mathrm{F}^{1 \mathrm{st}}$ & & & $6.8 \pm 0.5,27 \mathrm{dpi}$ & $4.0,27 \mathrm{dpi}$ & & & & \\
\hline & $\mathrm{RSV}_{\mathrm{B}}-\mathrm{G}^{1 \mathrm{st}}$ & & & $7.8 \pm 1.0,27 \mathrm{dpi}$ & $5.5,27 \mathrm{dpi}$ & & & & \\
\hline & $\mathrm{RSV}_{B}-\mathrm{F}^{1 \mathrm{st}} \mathrm{G}^{1 \mathrm{st}}$ & & & $7.3 \pm 0.8,27 \mathrm{dpi}$ & $\begin{array}{c}1.5 \text { (anti-F), } \\
5.5 \text { (anti-G), } 27 \text { dpi }\end{array}$ & & & & \\
\hline & RSV-F1st & \multirow{11}{*}{ hamsters } & \multirow{4}{*}{$1 \times 10^{6} \mathrm{TCID}_{50}$} & $10.1 \pm 0.2,28 \mathrm{dpi}$ & \multirow{12}{*}{ nd } & \multirow{4}{*}{$1 \times 10^{6} \mathrm{PFU}$ of RSV, $31 \mathrm{dpi}$} & $3.4 \pm 0.2,3 \mathrm{dpc}$ & $2.9 \pm 0.2,3 \mathrm{dpc}$ & \multirow{4}{*}{ [148] } \\
\hline & RSV-F $F^{2 n d}$ & & & $10.7 \pm 0.3,28 \mathrm{dpi}$ & & & $3.1 \pm 0.1,3 \mathrm{dpc}$ & $3.0 \pm 0.2,3 \mathrm{dpc}$ & \\
\hline & RSV-F F $^{3 r d}$ & & & $10.4 \pm 0.2,28 \mathrm{dpi}$ & & & $3.6 \pm 0.2,3 \mathrm{dpc}$ & $\leq 2.7,3 \mathrm{dpc}$ & \\
\hline & RSV-F'th & & & $11.0 \pm 0.4,28 \mathrm{dpi}$ & & & $4.0 \pm 0.2,3 \mathrm{dpc}$ & $3.1 \pm 0.3,3 \mathrm{dpc}$ & \\
\hline BPIV3 & $\mathrm{RSV}_{\mathrm{A}}-\mathrm{F}^{6 \mathrm{th}} \mathrm{G}^{6 \mathrm{th}}$ & & $1 \times 10^{6} \mathrm{PFU}$ & $5.4 \pm 0.7,21 \mathrm{dpi}$ & & $1 \times 10^{6} \mathrm{PFU}$ of RSV, $21 \mathrm{dpi}$ & $1.7 \pm 0.5,4 \mathrm{dpc}$ & $1.4 \pm 0.5,4 \mathrm{dpc}$ & [163] \\
\hline \multirow{9}{*}{ rB/HPIV3 } & RSV-F Fst $^{\text {st }}$ & & \multirow{6}{*}{$1 \times 10^{6} \mathrm{PFU}$} & $5.5 \pm 0.5,28 \mathrm{dpi}$ & & \multirow{4}{*}{$1 \times 10^{6} \mathrm{PFU}$ of RSV, $28 \mathrm{dpi}$} & $<0.8 \pm 0.1,4 \mathrm{dpc}$ & $<0.5 \pm 0.0,4 \mathrm{dpc}$ & \multirow{6}{*}{ [149] } \\
\hline & RSV-F $F^{2 n d}$ & & & $6.9 \pm 0.7,28 \mathrm{dpi}$ & & & $<1.3 \pm 0.6,4 \mathrm{dpc}$ & $<1.6 \pm 1.0,4 \mathrm{dpc}$ & \\
\hline & RSV-G G $^{1 s t}$ & & & $3.4 \pm 0.5,28 \mathrm{dpi}$ & & & $<1.0 \pm 0.3,4 \mathrm{dpc}$ & $<0.7 \pm 0.1,4 \mathrm{dpc}$ & \\
\hline & RSV-G ${ }^{2 n d}$ & & & $3.4 \pm 0.5,28 \mathrm{dpi}$ & & & $<0.8 \pm 0.1,4 \mathrm{dpc}$ & $<0.8 \pm 0.3,4 \mathrm{dpc}$ & \\
\hline & HMPV-Fist & & & $7.8 \pm 1.0,28 \mathrm{dpi}$ & & \multirow{2}{*}{$1 \times 10^{6} \mathrm{PFU}$ of HMPV, $28 \mathrm{dpi}$} & $3.5 \pm 0.8,4 \mathrm{dpc}$ & $<0.5 \pm 0.2,4 \mathrm{dpc}$ & \\
\hline & HMPV-F ${ }^{2 n d}$ & & & $7.4 \pm 1.0,28 \mathrm{dpi}$ & & & $<0.9 \pm 0.4,4 \mathrm{dpc}$ & $<0.5 \pm 0.1,4 \mathrm{dpc}$ & \\
\hline & HMPV-F $\mathrm{F}^{2 n d}$ & \multirow{3}{*}{ AGMs } & $6.4 \times 10^{5} \mathrm{PFU}$ & $\begin{array}{c}7.1 \pm 1.2\left(\mathrm{HMPV}_{2} \mathrm{~A}\right), \\
2.7 \pm 1.1\left(\mathrm{HMPV} \_\mathrm{B}\right), 28 \\
\mathrm{dpi}\end{array}$ & & $5 \times 10^{5} \mathrm{PFU}$ of HMPV, $28 \mathrm{dpi}$ & $2.3 \pm 1.1^{\mathrm{E}}$ & $<1.3 \pm 0.0^{\mathrm{F}}$ & [122] \\
\hline & RSV-F $\mathrm{F}^{2 n d}$ & & \multirow{2}{*}{$2^{\mathrm{D}} \times 2-3 \times 10^{5} \mathrm{PFU}$} & $\begin{array}{c}4.0 \pm 1.0(\text { RSV_A }) \\
3.4 \pm 1.8 \text { (RSV_B), } 28 \\
\text { dpi }\end{array}$ & $8.2,28 \mathrm{dpi}$ & \multirow{2}{*}{$7 \times 10^{5} \mathrm{PFU}$ of RSV, $28 \mathrm{dpi}$} & $<1.2 \pm 0.4^{\mathrm{E}}$ & $<1.2 \pm 0.3^{\mathrm{G}}$ & \multirow{2}{*}{ [121] } \\
\hline & RSV-F $\mathrm{F}^{2 \mathrm{nd}(\mathrm{SOL})}$ & & & $\begin{array}{c}4.1 \pm 1.5(\text { RSV_A), } \\
4.6 \pm 1.4 \text { (RSV_BB), } 28 \\
\text { dpi }\end{array}$ & 8.0, $28 \mathrm{dpi}$ & & $<1.1 \pm 0.2^{\mathrm{E}}$ & $<1.1 \pm 0.0^{\mathrm{G}}$ & \\
\hline
\end{tabular}

$\overline{\mathrm{A}} \mathrm{HMPV}$ or RSV, depending on the antigen inserted; ${ }^{\mathrm{B}}$ mean reciprocal $\log _{2}$-fold increase in $60 \%$ plaque reduction neutralization assay (PRNT60) \pm standard error of the difference (SE); ${ }^{\mathrm{C}}$ $\log _{2}$-fold increase in serum immunoglobulin $\mathrm{G}$ (IgG) titers determined by ELISA; ${ }^{\mathrm{D}}$ simultaneous immunization intranasally and intratracheally; ${ }^{\mathrm{E}}$ daily mean peak titers from 0 -11 dpc; ${ }^{\mathrm{F}}$ daily mean peak titers collected on $0,2,4,6$, and $8 \mathrm{dpc}$; ${ }^{\mathrm{G}}$ daily mean peak titers collected on $1,3,5,7$, and $9 \mathrm{dpc}$; ${ }^{\mathrm{H}}$ animals were immunized with a $10^{5} \mathrm{TCID}$;0 mixture of the two viruses; SOL: soluble protein lacking TMCT domains; RT: respiratory tract; URT and LRT: upper and lower RT, respectively; AGMs: African green monkeys; nd: not determined; dpi: days post the last immunization; dpc: days post challenge. 


\subsection{Human Parainfluenza Type 1}

Human parainfluenza type 1 (HPIV1) is the major cause of croup, and it is responsible for approximately $38 \%$ of HPIV infections in children before the age of 5 [164]. As it is an important pediatric pathogen with no protective vaccine available, the use of this virus as a backbone for a bivalent vaccine is highly warranted. HPIV1 shares the same genomic organization with other HPIV viruses. Recombinant HPIV1 tested as a vaccine in preclinical studies in AGMs (rHPIV-C ${ }^{R 84 G / \Delta 170} \mathrm{HN}^{553 \mathrm{~A}} \mathrm{~L}^{\mathrm{Y} 942 \mathrm{~A}}$ ) has been attenuated by mutations in its $\mathrm{P} / \mathrm{C}, \mathrm{HN}$, and $\mathrm{L}$ genes [165]. Tested as a vaccine in HPIV1-seropositive and HPIV1-seronegative children, it was shown to be well-tolerated but overattenuated [166]. Considering the additional attenuating effect of exogene insertion, subsequent studies concentrated on HPIV1 bearing just a single attenuating mutation-either $\mathrm{C}^{\Delta 170}$ or $\mathrm{L}^{\mathrm{Y} 942 \mathrm{~A}}$. The examples of HPIV1- based vaccines are shown in Table 2.

Mackow et al. tested rHPIV1-C ${ }^{\Delta 170}$ and rHPIV1-L ${ }^{\text {Y942A }}$ vectors for expression of RSV-F at the $1^{\text {st }}, 2^{\text {nd }}$, or $3^{\text {rd }}$ genomic positions [145]. They showed that rHPIV1- ${ }^{\text {Y942A }}$ backbone is overattenuated upon RSV-F insertions and that the rHPIV1- $C^{\Delta 170}$ backbone is a more suitable vector. rHPIV1-C $^{\Delta 170}$ has been subsequently tested to express either native RSV-F or chimeric RSV-F ${ }^{(T M C T)}$ protein from the $1^{\text {st }}$ and the $2^{\text {nd }}$ positions [155]. Wild type HPIV1 has been tested as a vector for expression of the $\mathrm{F}, \mathrm{G}$, and SH surface proteins of HMPV to examine their relative contribution to inducing HMPV-specific antibodies [54]. Contrary to $\mathrm{G}^{3 \mathrm{rd}}$ and $\mathrm{SH}^{3 \mathrm{rd}}$ insertions, $\mathrm{F}^{1 \mathrm{st}}$ insertion impaired virus growth and the expression of the vector's HN gene. Vaccination with HPIV1//HMPV-F1st provided significant protection against wt HMPV challenge, but even two doses were less protective than a single immunization with wt HMPV. This study showed that the HMPV-F is the major viral antigen, being more immunogenic than HMPV-G or SH [54]. The HPIV1 backbone was also used to express the F protein of HMPV_A and evaluate its ability to induce cross-protection against HMPV_B [6]. This study showed that the F protein of HMPV_A can induce cross-protection against a heterologous HMPV strain and that the HPIV1 backbone is suitable for vectoring HMPV antigens. 
Table 2. Examples of HPIV1-based vaccines against either RSV or HMPV with their immunogenicity and protection in animal models.

\begin{tabular}{|c|c|c|c|c|c|c|c|c|}
\hline \multicolumn{2}{|c|}{ Chimeric Vaccine } & \multicolumn{2}{|c|}{ Immunization } & \multirow{2}{*}{$\begin{array}{l}\text { Increase in Serum Virus } \\
\text { A-Neutralizing Antibody } \\
\text { Titers Post Immunization }\end{array}$} & \multirow{2}{*}{ Challenge } & \multicolumn{2}{|c|}{$\begin{array}{c}\text { Challenge Virus Titers in RT } \\
{\left[\log _{10} \mathrm{PFU} / \mathrm{g} \pm \mathrm{SE}\right]}\end{array}$} & \multirow{2}{*}{ Reference } \\
\hline Vector & Insert & Animal Model & Dose & & & URT & LRT & \\
\hline \multirow{4}{*}{ HPIV1 } & HMPV-F ${ }^{1 s t}$ & \multirow{14}{*}{ hamsters } & \multirow{2}{*}{$1 \times 10^{6} / 10^{6.4} \mathrm{TCID}_{50} \mathrm{D}$} & $8.3 \pm 0.4,26 \mathrm{dpi}$ & \multirow{3}{*}{$\begin{array}{c}1 \times 10^{5.7} \mathrm{TCID}_{50} \\
\text { of RSV, } 28 \mathrm{dpi}\end{array}$} & $3.3 \pm 0.2^{C}, 4 \mathrm{dpc}$ & $\leq 1.5 \pm 0.0^{C}, 4 \mathrm{dpc}$ & \multirow{3}{*}{ [54] } \\
\hline & HMPV-SH $^{3 \mathrm{rd}}$ & & & $\leq 2.9 \pm 0.0,26 \mathrm{dpi}$ & & $5.3 \pm 0.2^{C}, 4 \mathrm{dpc}$ & $2.7 \pm 0.1^{\mathrm{C}}, 4 \mathrm{dpc}$ & \\
\hline & HMPV-G ${ }^{3 r d}$ & & $1 \times 10^{6} / 10^{7.4}$ TCID $_{50} \mathrm{D}$ & $\leq 2.9 \pm 0.0,26 \mathrm{dpi}$ & & $4.6 \pm 0.5^{C}, 4 \mathrm{dpc}$ & $2.4 \pm 0.4^{C}, 4 \mathrm{dpc}$ & \\
\hline & $\mathrm{HMPV}_{\mathrm{A}}-\mathrm{F}^{1 \mathrm{st}}$ & & \multirow{7}{*}{$1 \times 10^{5} \mathrm{TCID}_{50}$} & $\begin{array}{c}6.0 \pm 0.8\left(\mathrm{HMPV}^{6} \text { _B), } 8.6 \pm 0.2\right. \\
\left(\mathrm{HMPV} \_\mathrm{A}\right), 33 \mathrm{dpi}\end{array}$ & $\begin{array}{c}1 \times 10^{5.5} \text { TCID }_{50} \\
\text { of HMPV_A or } \\
\text { B, } 50 \mathrm{dpi}\end{array}$ & $\begin{array}{c}2.9 \pm 0.3\left(\mathrm{HMPV} \_\mathrm{B}\right) \\
3.9 \pm 0.1 \\
\text { (HMPV_A), } 4 \mathrm{dpc}\end{array}$ & nd & {$[6]$} \\
\hline \multirow{3}{*}{$\begin{array}{l}\text { rHPIV1- } \\
\text { LY942A }\end{array}$} & RSV-F$^{1 \mathrm{st}}$ & & & $<3.3,28 \mathrm{dpi}$ & \multirow{10}{*}{$\begin{array}{c}1 \times 10^{6} \mathrm{PFU} \text { of } \\
\mathrm{RSV}, 30 \mathrm{dpi}\end{array}$} & $7.0,3 \mathrm{dpc}$ & $6.1,3 \mathrm{dpc}$ & \multirow{6}{*}{ [145] } \\
\hline & RSV-F ${ }^{2 n d}$ & & & $<3.3,28$ dpi & & $6.9,3 \mathrm{dpc}$ & $4.9,3 \mathrm{dpc}$ & \\
\hline & RSV-F ${ }^{3 r d}$ & & & $<3.3,28 \mathrm{dpi}$ & & $6.7,3 \mathrm{dpc}$ & $6.0,3 \mathrm{dpc}$ & \\
\hline \multirow{7}{*}{ rHPIV1- C $\Delta 170$} & RSV-F 1 st & & & $7.3 \pm 0.3,28 \mathrm{dpi}$ & & $4.8,3 \mathrm{dpc}$ & $3.7,3 \mathrm{dpc}$ & \\
\hline & RSV-F ${ }^{2 n d}$ & & & $4.7 \pm 0.7,28 \mathrm{dpi}$ & & $6.2,3 \mathrm{dpc}$ & $4.3,3 \mathrm{dpc}$ & \\
\hline & RSV-F ${ }^{3 r d}$ & & & $6.7 \pm 0.8,28 \mathrm{dpi}$ & & $5.5,3 \mathrm{dpc}$ & $4.3,3 \mathrm{dpc}$ & \\
\hline & $\mathrm{RSV}^{\mathrm{N}} \mathrm{F}^{1 \mathrm{st}(\mathrm{PF})}$ & & \multirow{4}{*}{$1 \times 10^{6} \mathrm{TCID}_{50}$} & $9.58 / 4.87^{\mathrm{E}}, 28 \mathrm{dpi}$ & & $4.47,3 \mathrm{dpc}$ & $3.04,3 \mathrm{dpc}$ & \multirow{4}{*}{ [155] } \\
\hline & RSV-F Fd(PF) $^{2 n}$ & & & $6.90 / 2.58^{\mathrm{E}}, 28 \mathrm{dpi}$ & & $4.81,3 \mathrm{dpc}$ & $4.16,3 \mathrm{dpc}$ & \\
\hline & RSV-F ${ }^{1 \mathrm{st}(\mathrm{PF}, \mathrm{TMCT})}$ & & & $6.08 / 3.33^{\mathrm{E}}, 28 \mathrm{dpi}$ & & $4.76,3 \mathrm{dpc}$ & $4.04,3 \mathrm{dpc}$ & \\
\hline & RSV-F F $^{2 n d(P F, T M C T)}$ & & & $4.38 / 2.53^{\mathrm{E}}, 28 \mathrm{dpi}$ & & $5.38,3 \mathrm{dpc}$ & $4.65,3 \mathrm{dpc}$ & \\
\hline
\end{tabular}

${ }^{\mathrm{A}} \mathrm{HMPV}$ or RSV, depending on the antigen inserted; ${ }^{\mathrm{B}}$ mean reciprocal $\log _{2}$-fold increase in PRNT60 $\pm \mathrm{SE} ;{ }^{\mathrm{C}} \log _{10} \mathrm{TCID}_{50} / \mathrm{g} \pm \mathrm{SE}$; ${ }^{\mathrm{D}}$ the dose of the prime/boost immunization; ${ }^{\mathrm{E}}$ values measured with/without added guinea pig complement; RT: Respiratory tract; URT and LRT: upper and lower RT, respectively; PF: pre-fusion form of RSV-F; TMCT: chimeric form of RSV-F where transmembrane (TM) and cytoplasmic (CT) domains were exchanged for their counterparts from the vector; nd: not determined; dpi: days post the last immunization; dpc: days post challenge. 


\subsection{Sendai Virus}

Sendai virus $(\mathrm{SeV})$ is a murine parainfluenza type 1 virus. Its natural host range restriction provides safety for humans, with no risk of reversion of the attenuated phenotype and it is capable of inducing durable and strong immune responses [167]. SeV is closely related to HPIV1 and has been developed as a heterologous vaccine that increases protection from HPIV1 infections in animal models and in humans [168-170]. The length of the SeV genome is of approximately $15.3 \mathrm{~kb}$ and the virus strictly adheres to the rule of six for efficient replication [171].

$\mathrm{SeV}$ has been shown to accommodate and stably express inserts up to $3.2 \mathrm{~kb}$ in size with the replication rate inversely correlated with the total genome length [172]. It has been broadly used as a backbone for expressing RSV-F or G proteins from its $5^{\text {th }}$ genomic positions and tested as a vaccine alone $[151,152,173-175]$ or in formulations of multiple recombinant $\mathrm{SeV}$ expressing the antigens of different HPIV types $[176,177]$. The $5^{\text {th }}$ genomic position was also used for the expression of HMPV-F [153]. The virus was recovered by reverse genetics, although there was a deletion in the exogene's sequence that resulted in expression of a truncated HMPV-F protein. It was 303 amino acids in length, retaining the F2 part (comprising of a signal peptide, fusion peptide and heptad repeat A) and a fragment of the F1 part, lacking Heptad Repeat B and both TM and CT domains. Although truncated, the protein was immunogenic and conferred protection against wt HMPV_A1 and A2 in immunized hamsters. This study showed that vectoring HMPV antigens with $\mathrm{SeV}$ is a promising strategy and that a soluble form of the HMPV-F protein remains immunogenic [153]. The examples of these chimeric $\mathrm{SeV}$ are shown in Table 3.

Table 3. Examples of SeV-based vaccines against either RSV or HMPV with their immunogenicity and protection in animal models.

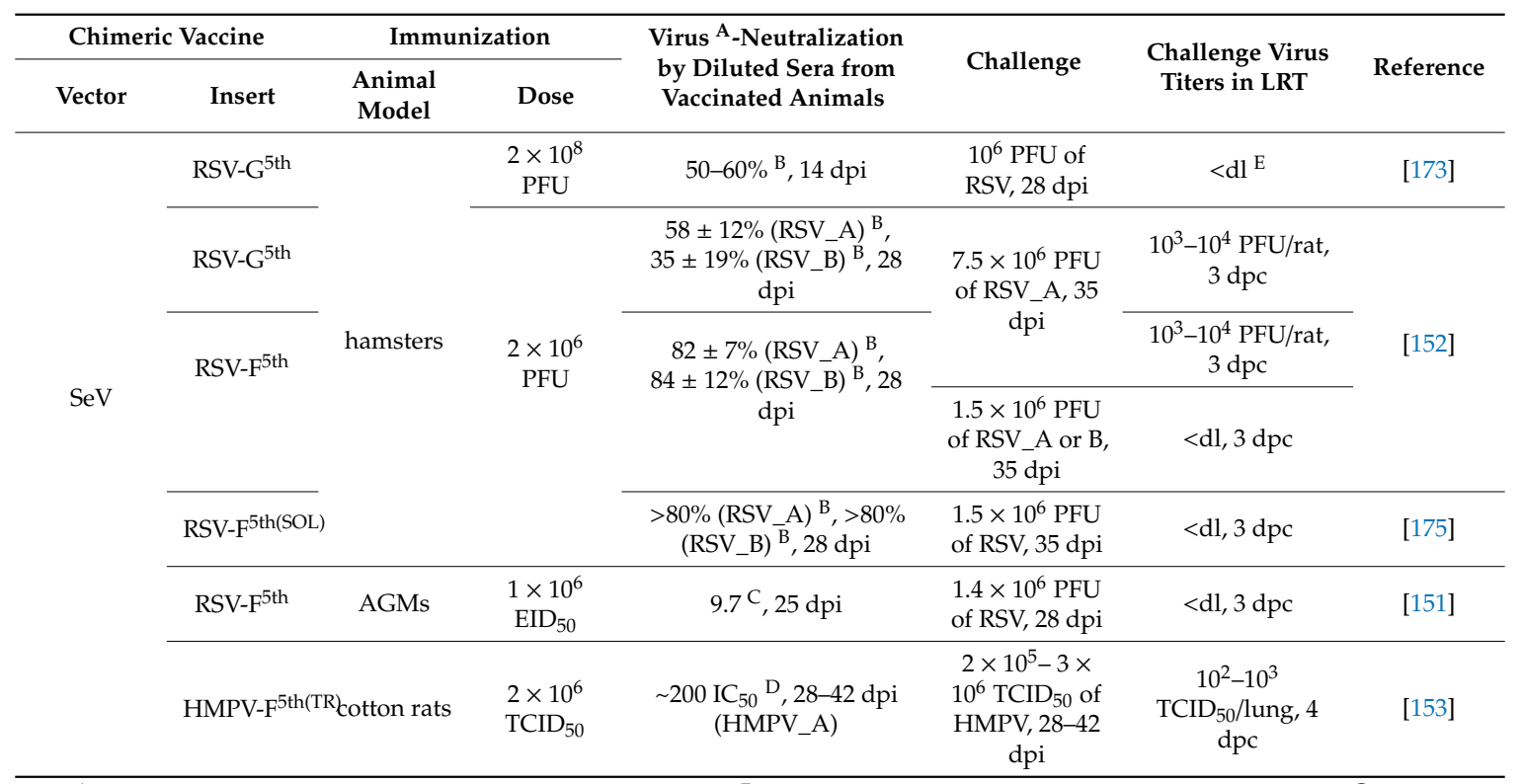

${ }^{\text {A }}$ HMPV or RSV, depending on the antigen inserted; ${ }^{B}$ mean $\%$ plaque reduction by sera diluted $1: 64 ;{ }^{C}$ mean reciprocal $\log _{2}$-fold increase in PRNT60; ${ }^{\mathrm{D}}$ serum dilution at which $50 \%$ of virus infection was inhibited $\left(\mathrm{IC}_{50}\right) ;{ }^{\mathrm{E}}$ mean virus titers from 3, 5, 7, and $10 \mathrm{dpc}$; LRT: lower respiratory tract; SOL: soluble version of the antigen; TR: truncated protein; AGMs: African green monkeys; EID $_{50}$ : 50\% effective infectious dose in eggs; dpi: days post the last immunization; dpc: days post challenge; <dL: below the detection limit, not detected.

\subsection{Newcastle Disease Virus}

Newcastle disease virus, an avian paramyxovirus serotype 1 (APMV1) virus, is an important poultry pathogen that recently drew a lot of attention for its potential use both as an oncolytic agent and as a vaccine vector. Although it is recognized as an avian pathogen, it has been experimentally proven to infect several mammal species including mice, hamsters, guinea pigs, rabbits, ferrets, calves, pigs, 
and non-human primates. Natural NDV infections are very rare in humans; the cases of infection have been documented in bird handlers exposed to the virus [178,179] and no human-to-human transmission has ever been observed [180]. Various NDV strains are classified as low virulent (lentogenic), mildly virulent (mesogenic), or highly virulent (velogenic). Concerning the high contagiousness of NDV and its potentially detrimental impact on the poultry industry, lentogenic strains of NDV were classified as biosafety level 2 (BSL-2) pathogens, with mesogenic and velogenic strains being BSL-3 pathogens [181]. Some lentogenic strains, namely, LaSota and B1, are used as naturally-attenuated vaccines to protect the poultry. Although mesogenic NDV strains are not frequently used as vaccine vectors, a mesogenic strain Beaudette C (BC) tested as a vaccine vector for the HPIV3-HN protein in non-human primates was well-tolerated and more immunogenic compared to the LaSota strain [182].

Similarly to $\mathrm{SeV}, \mathrm{NDV}$ is safe in humans due to a natural host range restriction with no presence of pre-existing immunity. It is highly immunogenic, inducing a potent IFN type 1 response [183]. Its genome is approximately $15.2 \mathrm{~kb}$ in length and the virus adheres to the rule of six for efficient replication [180]. The virus can accommodate exogenes up to $4.5 \mathrm{~kb}$ in length and it can effectively express three additional proteins [184]. An exogene can be placed at the gene junction between any two genes of the virus, yet the $3^{\text {rd }}$ position has been found to be the most optimal for NDV vector $[149,182,185,186]$ with the $1^{\text {st }}$ and the $2^{\text {nd }}$ ones being the least optimal $[148,149]$. NDV has been used for vectoring the antigens of RSV [185], AMPV [187-189], HIV [149,190,191], HPIV3 [182], influenza A virus [192], SARS-coronavirus [186], Nipah virus [193], and Ebola virus [194]. Examples of NDV vectoring pneumoviral antigens are reported in Table 4.

Although NDV has not yet been used as a vector for HMPV antigens, it was found to be an efficient backbone for surface proteins of AMPV_C. LaSota NDV strain has been used for vectoring the G protein of AMPV_C and tested as a bivalent vaccine against NDV and AMPV_C in turkeys [187]. The NDV//AMPV ${ }_{C}-G^{5 \text { th }}$ virus conferred partial protection in $50 \%$ of vaccinated birds, indicating that AMPV_C-G protein alone is not sufficient to induce protective immunity. The immunogenicity of this construct was strongly improved when AMPV_C-F and G proteins were expressed together from the $5^{\text {th }}$ genomic position of NDV genome [189]. Similarly to HMPV, the F protein of AMPV_C is indispensable to induce a potent immune response in a vaccinated host.

Table 4. Examples of NDV-based vaccines against either RSV or AMPV with their immunogenicity and protection in animal models.

\begin{tabular}{|c|c|c|c|c|c|c|c|}
\hline \multicolumn{2}{|c|}{ Chimeric Vaccine } & \multicolumn{2}{|c|}{ Immunization } & \multirow{2}{*}{$\begin{array}{c}\text { Sera positive for } \\
\text { virus }{ }^{A} \text {-Neutralizing } \\
\text { antibodies }^{B}\end{array}$} & \multirow{2}{*}{ Challenge } & \multirow{2}{*}{$\begin{array}{l}\text { Challenge Virus } \\
\text { in LRT }\end{array}$} & \multirow[b]{2}{*}{ Reference } \\
\hline Vector & Insert & $\begin{array}{c}\text { Animal } \\
\text { Model }\end{array}$ & Dose & & & & \\
\hline \multirow{9}{*}{ NDV } & RSV-F $\mathrm{F}^{3 \mathrm{rd}}$ & $\begin{array}{c}\mathrm{BALB} / \mathrm{c} \\
\text { mice }\end{array}$ & $\begin{array}{c}5 \times 10^{5} \\
\text { PFU }\end{array}$ & nd & $\begin{array}{c}1 \times 10^{7} \mathrm{PFU} \text { of } \\
\text { RSV } \\
28 \mathrm{dpi}\end{array}$ & $\begin{array}{c}1 \times 10^{4} \mathrm{PFU} / \mathrm{g} \\
5 \mathrm{dpc}\end{array}$ & [185] \\
\hline & \multirow[t]{2}{*}{$\mathrm{AMPV}_{\mathrm{C}}-\mathrm{G}^{5 \text { th }}$} & \multirow{8}{*}{ turkeys } & $\begin{array}{l}1 \times 10^{6} \\
\operatorname{TCID}_{50}\end{array}$ & $40 \%{ }^{\mathrm{C}}$ & \multirow{2}{*}{$\begin{array}{l}4.2 \times 10^{3} \mathrm{ID}_{50} \text { of } \\
\text { AMPV_C, } 14 \mathrm{dpi}\end{array}$} & $100 \% / 90 \% / 70 \% \mathrm{E}^{\mathrm{E}}$ & \multirow[t]{2}{*}{ [187] } \\
\hline & & & $\begin{array}{c}2^{\mathrm{D}} \times 10^{6} \\
\operatorname{TCID}_{50}\end{array}$ & $40 \% / 50 \%{ }^{\mathrm{C}}$ & & $100 \% / 100 \% / 80 \%$ E & \\
\hline & $\mathrm{AMPV}_{\mathrm{A}}-\mathrm{G}^{5 \text { th }}$ & & $1 \times 10^{6}$ & & \multirow{6}{*}{$\begin{array}{c}1 \times 10^{2} \mathrm{ID}_{50} \text { of } \\
\text { AMPV_A or B } \\
14 \mathrm{dpi}\end{array}$} & $100 \% / 100 \% / 30 \%{ }^{\mathrm{F}}$ & \multirow{2}{*}{ [188] } \\
\hline & $\mathrm{AMPV}_{\mathrm{B}}-\mathrm{G}^{5 \text { th }}$ & & \multirow{3}{*}{$\begin{array}{l}1 \times 10^{6} \\
\operatorname{TCID}_{50}\end{array}$} & nd & & $100 \% / 100 \% / 50 \%{ }^{\mathrm{F}}$ & \\
\hline & $\mathrm{AMPV}_{\mathrm{C}}-\mathrm{G}^{5 \text { th }}$ & & & $40 \%{ }^{C}$ & & $100 \% / 100 \% / 80 \%{ }^{\mathrm{E}}$ & \multirow{4}{*}{ [189] } \\
\hline & $\mathrm{AMPV}_{\mathrm{C}^{-}} \mathrm{G}^{5 \text { th }} \mathrm{F}^{5 \text { th }}$ & & & $70 \% \mathrm{C}$ & & $100 \% / 100 \% / 60 \%{ }^{\mathrm{E}}$ & \\
\hline & $\mathrm{AMPV}_{\mathrm{C}}-\mathrm{G}^{5 \text { th }}$ & & \multirow{2}{*}{$\begin{array}{c}2^{\mathrm{D}} \times 10^{6} \\
\operatorname{TCID}_{50}\end{array}$} & $40 \% / 50 \%{ }^{C}$ & & $100 \% / 90 \% / 70 \%{ }^{\mathrm{E}}$ & \\
\hline & $\mathrm{AMPV}_{\mathrm{C}^{-}} \mathrm{G}^{5 \text { th }} \mathrm{F}^{5 \text { th }}$ & & & $60 \% / 100 \% \mathrm{C}$ & & $100 \% / 80 \% / 20 \% \mathrm{E}$ & \\
\hline
\end{tabular}

A AMPV_C or RSV, depending on the antigen inserted; ${ }^{\mathrm{B}}$ determined by ELISA; $\mathrm{C} \%$ of immunized birds that seroconverted at $14 \mathrm{dpi}$ (after single immunization) or at $14 / 28 \mathrm{dpi}$ (after prime/boost immunization); ${ }^{\mathrm{D}}$ prime and boost immunizations in 2-weeks interval; $\mathrm{E} \%$ of birds with detected challenge virus RNA shedding, results for 3/5/7 $\mathrm{dpi}$; $\mathrm{F} \%$ of birds with detected challenge virus RNA shedding, results for $5 / 7 / 9 \mathrm{dpc}$; ID 50 : $50 \%$ infective dose; LRT: lower respiratory tract; dpi: days post immunization; dpc: days post challenge. 


\subsection{Vesicular Stomatitis Virus}

Vesicular stomatitis virus is a pathogen of horses and livestock, belonging to the Rhabdoviridae family. Rhabdoviridae and Paramyxoviridae both belong to the same order of negative-strand viruses, Mononegavirales. The genome of VSV is a single-stranded, nonsegmented RNA of negative polarity of approximately $11.1 \mathrm{~kb}$ in length and, due to the simplicity of its genome, it was used as a model to study the transcription and replication of nonsegmented negative-stranded viruses (NNSV) (Figure 5) [121].

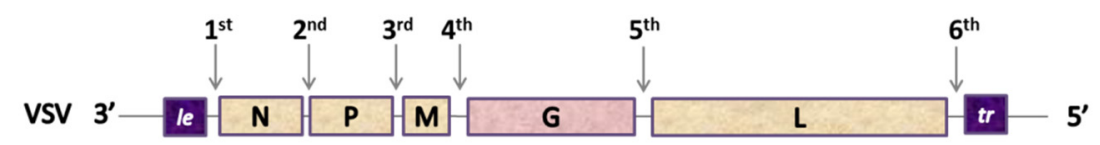

Figure 5. The organization of the genome of VSV with the indication of insert positions.

VSV shares the same advantages as a viral vector with paramyxoviruses, although with superior growth in vitro [195]. It provides a good level of protein expression: Chloramphenicol acetyltransferase protein (CAT) expressed from the $5^{\text {th }}$ position of VSV genome constituted $1.7 \%$ of all the proteins produced by rVSV-infected cells [195]. The expression of VSV genes follows the polar gradient observed for paramyxoviruses, and 3'-proximal insert positions influencing N:P proteins ratio, can be detrimental for virus replication. An N:P ratio between 1:1 and 2:1 has been shown optimal for viral replication, whereas a ratio below or above this value was associated with decreased replicative capacity of the virus [196].

VSV vector has two potential drawbacks, namely, neurotoxicity mediated by its G protein $[197,198]$ and induction of a potent VSV-neutralizing antibody response specific to its G protein even upon a single immunization, which makes the boost with a heterologous vaccine impossible and limits the future use of VSV-based vaccines for the vaccinated patient [199]. This neurotropism results in significant viral replication in brain and mortality in mice infected by VSV [200], raising some serious concerns about using this virus as a vaccine vector. Although VSV is not a human pathogen, some human infection can occur as a result of contact with infected animals [201-203]. One case of encephalitis caused by VSV infection was reported in a 3-year-old boy from Panama [204]. Because of significant morbidity in VSV-infected cattle, VSV has been included in the list of potentially harmful agents by the United States Department of Agriculture [205].

To circumvent the problem of G-mediated VSV neurotoxicity, an attenuated VSV in which the G protein had been exchanged for the GP protein of lymphocytic choriomeningitis virus (LCMV), called rVSV-GP, has been designed [206]. This chimeric virus was used to express the RSV-F protein at the $5^{\text {th }}$ genomic position in three variants: native, codon-optimized, and codon-optimized with TMCT domain exchange [207]. Efficient expression of native RSV-F and RSV-G proteins from the $5^{\text {th }}$ and the $4^{\text {th }}$ genomic positions, respectively, has been also documented for rVSV, but the viruses were not tested in vivo [208]. RSV-F5th constructs were also tested in the context of a VSV backbone attenuated as a result of $\mathrm{G}$ protein deletion $(\mathrm{rVSV} \Delta \mathrm{G})$ [209]. The studies showed that $\mathrm{rVSV} \Delta \mathrm{G}$ backbone is more attenuated and less immunogenic than rVSV and that the combination rVSV $\Delta G$ with RSV-G antigen was not efficient for immunization. A non-propagating recombinant VSV bearing a deletion in the membrane-proximal domain of its G protein (VSV-G ${ }^{\text {STEM }}$ ) was used to vector RSV-F and G proteins and tested in vivo as an intranasal or intramuscular vaccine [210].

VSV has also been used to express the HMPV-F protein in a study aimed to design an enzyme-linked immunosorbent assay (ELISA) specific for HMPV [21]. The study showed that it is possible to efficiently express HMPV-F protein from the $2^{\text {nd }}$ genomic position of the VSV vector. The examples of VSV-based chimeric vaccines are described in Table 5. 
Table 5. Examples of VSV-based vaccines against either RSV or AMPV with their immunogenicity and protection in animal models.

\begin{tabular}{|c|c|c|c|c|c|c|c|c|c|}
\hline \multicolumn{2}{|c|}{ Chimeric Vaccine } & \multicolumn{2}{|c|}{ Immunization } & \multirow{2}{*}{$\begin{array}{l}\text { Serum Neutralizing Antibody } \\
\text { Titers Post Immunization }\end{array}$} & \multirow{2}{*}{$\begin{array}{c}\text { RSV ELISA } \\
\text { Titer }^{B}\end{array}$} & \multirow{2}{*}{ Challenge } & \multicolumn{2}{|c|}{ Challenge Virus Titers in RT } & \multirow[t]{2}{*}{ Referenc } \\
\hline Vector & Insert & $\begin{array}{l}\text { Animal } \\
\text { Model }\end{array}$ & Dose & & & & URT & LRT & \\
\hline \multirow{2}{*}{ vSV } & RSV-F $F^{4 \text { th }}$ & \multirow{14}{*}{$\mathrm{BALB} / \mathrm{c}$ mice } & \multirow{2}{*}{$2^{\mathrm{D}} \times 10^{4} \mathrm{PFU}$} & $1: 32^{\mathrm{A}}$ & 4.096 & \multirow{4}{*}{$\begin{array}{c}1.2 \times 10^{5} \mathrm{PFU} \text { of RSV, } \\
28 \mathrm{dpi}\end{array}$} & $<50 \mathrm{PFU} / \mathrm{mL}, 4 \mathrm{dpc}$ & $<50 \mathrm{PFU} / \mathrm{mL}, 4 \mathrm{dpc}$ & \multirow{4}{*}{ [209] } \\
\hline & RSV-G ${ }^{4 \text { th }}$ & & & $1: 16^{\mathrm{A}}$ & 128 & & $<50 \mathrm{PFU} / \mathrm{mL}, 4 \mathrm{dpc}$ & $<50 \mathrm{PFU} / \mathrm{mL}, 4 \mathrm{dpc}$ & \\
\hline \multirow[b]{2}{*}{$\mathrm{rVSV} \Delta \mathrm{G}$} & RSV-F $F^{4 \text { th }}$ & & $3^{\mathrm{E}} \times 1.25 \times 10^{3} \mathrm{PFU}$ & $<1: 8^{\mathrm{A}}$ & 1.024 & & $<50 \mathrm{PFU} / \mathrm{mL}, 4 \mathrm{dpc}$ & $<50 \mathrm{PFU} / \mathrm{mL}, 4 \mathrm{dpc}$ & \\
\hline & RSV-G ${ }^{4 \text { th }}$ & & $3^{\mathrm{E}} \times 10^{4} \mathrm{PFU}$ & $<1: 8^{\mathrm{A}}$ & $<64$ & & $\begin{array}{c}1 \times 10^{4.2} \mathrm{PFU} / \mathrm{mL}, 4 \\
\mathrm{dpc}\end{array}$ & $\begin{array}{c}1 \times 10^{5.4} \mathrm{PFU} / \mathrm{mL}, 4 \\
\mathrm{dpc}\end{array}$ & \\
\hline \multirow[t]{2}{*}{ rVSV-GP } & \multirow{2}{*}{ RSV-F $F^{5 \text { th }}$ CO } & & $1 \times 10^{7} \mathrm{TCID}_{50}$ & $\sim 6.9 \log _{2} \mathrm{IC}_{50} \mathrm{G}$ & \multirow{10}{*}{ nd } & \multirow{2}{*}{$\begin{array}{c}1 \times 10^{6} \mathrm{PFU} \text { of RSV } \\
28 \mathrm{dpi}\end{array}$} & \multirow{2}{*}{ nd } & $\begin{array}{c}\sim 4.45 \log _{10} \text { RSV } \\
\text { copies/ug RNA, } 5 \\
\text { dpc }\end{array}$ & \multirow{2}{*}[207]{} \\
\hline & & & $3^{\mathrm{F}} \times 10^{7} \mathrm{TCID}_{50}$ & $\sim 6.53 / \sim 9.5 / \sim 8.68{ }^{\mathrm{H}} \log _{2} \mathrm{IC}_{50} \mathrm{G}$ & & & & 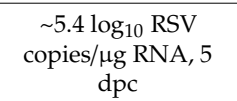 & \\
\hline \multirow{8}{*}{ rVSV-G GTEM $^{\text {STE }}$} & RSV-F $F^{1 s t}$ & & \multirow{2}{*}{$2 \times 10^{7} \mathrm{PFU}^{\mathrm{I}}$} & $\begin{array}{c}\text { prime: } 3.2 / 1.8 \text {; boost: } 3.8 / 3.0 \\
\text { (RSV_A); } 2.4 \text { (RSV_B) }{ }^{\mathrm{J}}\end{array}$ & & \multirow{2}{*}{$\begin{array}{c}1 \times 10^{6} \mathrm{PFU} \text { of RSV_A } \\
\text { or } 2 \times 10^{5} \mathrm{PFU} \text { of } \\
\text { RSV_B, } 28 \mathrm{dpi}\end{array}$} & $\begin{array}{c}\sim 1 \times 10^{1} \mathrm{PFU} / \mathrm{g}, \\
100 \% \mathrm{~m}\end{array}$ & $\begin{array}{c}1 \times 10^{0}-10^{1} \mathrm{PFU} / \mathrm{g} \\
100 \% \mathrm{M}\end{array}$ & \multirow{8}{*}{ [210] } \\
\hline & RSV-F-Frd & & & $\begin{array}{c}\text { prime: } 3.3 / 1.9 \text {; boost: } 3.4 / 3.0 \\
\text { (RSV_A); } 2.7 \text { (RSV_B) J }\end{array}$ & & & $\begin{array}{c}\sim 1 \times 10^{1} \mathrm{PFU} / \mathrm{g} \\
100 \% \mathrm{M}\end{array}$ & $\begin{array}{c}1 \times 10^{0}-10^{1} \mathrm{PFU} / \mathrm{g}, \\
100 \% \mathrm{M}\end{array}$ & \\
\hline & RSV-F1st & & & $2.19 / 1.34 \mathrm{~L}$ & & & $\begin{array}{c}1 \times 10^{2}-10^{3} \mathrm{PFU} / \mathrm{g}, \\
0 \%{ }^{\mathrm{M}}\end{array}$ & $1 \times 10_{\mathrm{M}}^{3} \mathrm{PFU} / \mathrm{g}, 70 \%$ & \\
\hline & RSV-F $\mathrm{F}^{3 \mathrm{rd}}$ & & $1 \times 10^{6} \mathrm{PFU}^{\mathrm{K}}$ & $2.65 / 1.46^{\mathrm{L}}$ & & & $\begin{array}{c}1 \times 10^{1}-10^{2} \mathrm{PFU} / \mathrm{g}, \\
10 \% \mathrm{M}\end{array}$ & $\begin{array}{c}1 \times 10^{2}-10^{3} \mathrm{PFU} / \mathrm{g} \\
90 \% \mathrm{M}\end{array}$ & \\
\hline & RSV-F $\mathrm{F}^{5 \text { th }}$ & & & $2.63 / 1.62^{\mathrm{L}}$ & & $\begin{array}{l}1 \times 10^{6} \text { PFU of } \\
\text { RSV_A, } 28 \text { dpi }\end{array}$ & $\begin{array}{c}1 \times 10^{1}-10^{2} \mathrm{PFU} / \mathrm{g}, \\
0 \%{ }^{\mathrm{M}}\end{array}$ & $\begin{array}{c}1 \times 10^{2}-10^{3} \mathrm{PFU} / \mathrm{g} \\
80 \% \mathrm{M}\end{array}$ & \\
\hline & RSV-F $F^{3 r d}$ & & \multirow{2}{*}{$1 \times 10^{5} \mathrm{PFU}$} & 4.68 (anti-F), $<2.0$ (anti-G) & & & $\begin{array}{c}1 \times 10^{2}-10^{3} \mathrm{PFU} / \mathrm{g} \\
0 \%^{\mathrm{M}} \\
\end{array}$ & $\begin{array}{c}1 \times 10^{1}-10^{2} \mathrm{PFU} / \mathrm{g} \\
40 \%{ }^{\mathrm{M}} \\
\end{array}$ & \\
\hline & RSV-G ${ }^{3 \mathrm{rd}}$ & & & $<2.0$ (anti-F), 4.42 (anti-G) & & & $\sim 1 \times 10_{\mathrm{M}}^{3} \mathrm{PFU} / \mathrm{g}, 0 \%$ & $\begin{array}{c}1 \times 10^{1}-10^{2} \mathrm{PFU} / \mathrm{g} \\
50 \% \mathrm{M}\end{array}$ & \\
\hline & $\underset{G^{3 r d}}{R S V-F^{3 r d}}$ and & & $\begin{array}{l}1 \times 10^{5} \text { PFU of the } \\
\text { two viruses }\end{array}$ & 4.55 (anti-F), 4.58 (anti-G) & & & $\begin{array}{c}1 \times 10^{2}-10^{3} \mathrm{PFU} / \mathrm{g} \\
0 \% \mathrm{M}\end{array}$ & $\begin{array}{c}1 \times 10^{0}-10^{1} 1 \\
\mathrm{PFU} / \mathrm{g}, 100 \% \mathrm{M}\end{array}$ & \\
\hline
\end{tabular}

${ }^{A}$ the last serum dilution in which RSV CPE was not detected, measured at $14 \mathrm{dpi}^{\mathrm{B}}$ dilution of pooled mouse serum which corresponded to an OD 450 of 0.5 ; ${ }^{\mathrm{C}}$ viral RNA shedding in LRT of the birds; results for $3 / 5 / 7 \mathrm{dpi}$; ${ }^{\mathrm{D}}$ prime and boost immunizations in 2-week intervals; ${ }^{\mathrm{E}}$ prime and two boost immunizations in 2 -week intervals; ${ }^{\mathrm{F}}$ mice were immunized 3 times by intramuscular injection in 4-week intervals; ${ }^{\mathrm{G}}$ serum dilution, at which $50 \%$ of virus infection was inhibited (IC50); ${ }^{\mathrm{H}}$ values determined after the prime immunization/1st boost/2nd boost, i.e., $28 / 56 \mathrm{dpi}$; I prime and boost immunizations by intramuscular injection in 4 -week intervals; ${ }^{\mathrm{J}}$ values $\log _{10} \mathrm{PRNT}_{60}$ measured with/ without added guinea pig complement $28 \mathrm{dpi}$ and 28 $\mathrm{dp}$ boost immunization. Values for anti RSV_B antibodies were determined only without the complement $28 \mathrm{dp}$ boost immunization; ${ }^{\mathrm{K}}$ immunizations by intramuscular injection with no boost; ${ }^{\mathrm{L}}$ values $\log _{10} \mathrm{PRNT}_{60}$ measured with/ without added guinea pig complement $28 \mathrm{dpi}$; ${ }^{\mathrm{M}} \%$ of vaccinated mice that were protected against RSV 4 days post challenge; RT: Respiratory tract; URT and LRT: upper and lower RT; CO: codon-optimized; dpi: days post the last immunization; dpc: days post challenge. 


\subsection{Recombinant Chimeric HMPV}

The only chimeric vaccine against HMPV advanced to clinical trials so far is a recombinant HMPV virus rendered less-infectious as a result of replacing its P ORF with the counterpart of a closely-related AMPV_C [116]. This strategy of attenuation is based on the restriction of replication in vivo based on the host incompatibility of some of the viral components. In the first study, an HMPV chimera with either N (rHMPV-N $\mathrm{A})$ or P (rHMPV-P $\left.{ }_{\mathrm{A}}\right)$ gene exchanged for its AMPV_C counterpart was tested as a vaccine in hamsters and AGMs (Table 6). The N and P genes of AMPV_C share 75 and 68\% nucleotide sequence identity with their HMPV counterparts, which suggested good integration of heterologous proteins into the HMPV particle [4,211]. $r H M P V-\mathrm{N}_{\mathrm{A}}$ and $\mathrm{rHMPV}-\mathrm{P}_{\mathrm{A}}$ viruses replicated more efficiently in vitro, compared to their parental HMPV strain. When tested in vivo in hamsters, the replication of both chimeric viruses was decreased 100-fold, and $\mathrm{rHMPV}_{\mathrm{N}} \mathrm{N}_{\mathrm{A}}$ was slightly more attenuated than rHMPV-P $\mathrm{A}_{\mathrm{A}}$. Both chimeras were equally immunogenic and protected the vaccinated animals from $\mathrm{wt}$ HMPV infection. When tested in AGMs, rHMPV-P $\mathrm{P}_{\mathrm{A}}$ was more attenuated than $\mathrm{rHMPV}-\mathrm{N}_{\mathrm{A}}$ and was almost equally immunogenic, and both chimeras conferred protection against wt HMPV [116]. This study identified the more attenuated HMPV-P $\mathrm{P}_{\mathrm{A}}$ chimera as a more promising vaccine candidate for further development. The rHMPV-P $\mathrm{A}$ virus has been recently tested as a vaccine in phase 1 clinical trial sequentially in adults, HMPV-seropositive and HMPV-seronegative children (NCT01255410) [25]. The trial found $\mathrm{rHMPV}-\mathrm{P}_{\mathrm{A}}$ virus being appropriately restricted in adults and seropositive children, yet insufficiently infectious and immunogenic in HMPV-seronegative children, thus leaving no other candidates for an anti-HMPV vaccine in clinical trials.

Table 6. The results of preclinical trials of $r H M P V-N_{A}$ and $\mathrm{rHMPV}_{\mathrm{P}} \mathrm{P}_{\mathrm{A}}$ in hamsters and AGMs.

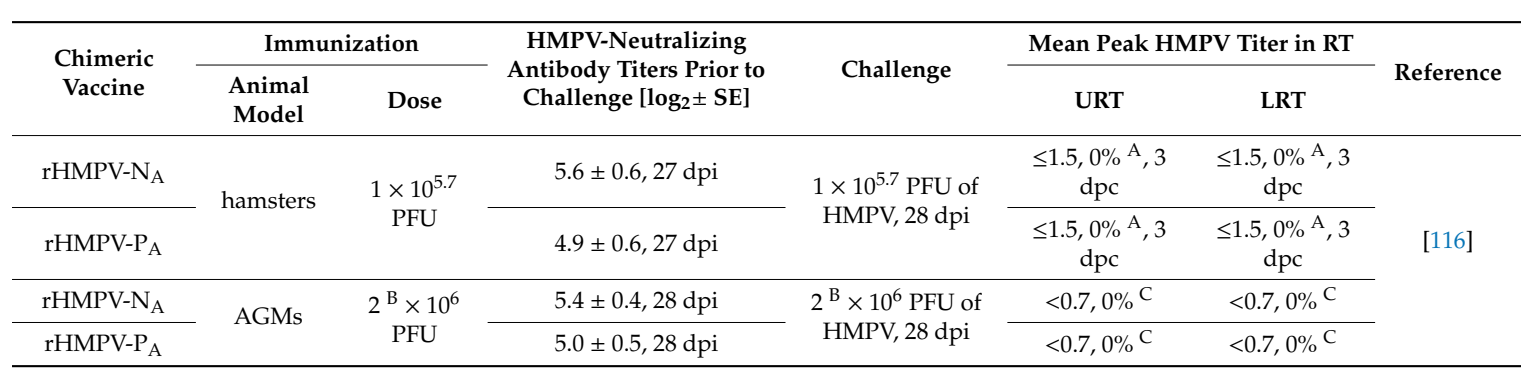

${ }^{A}$ mean HMPV titer $\log _{10}$ PFU/g of tissue, $\%$ of animals with detectable challenge virus; ${ }^{B}$ simultaneous inoculation intranasally and intratracheally; ${ }^{C}$ samples collected on $2,4,6,8 \mathrm{dpc}$, virus titers determined by plaque assay with detection limit $0.7 \log _{10} \mathrm{PFU} / \mathrm{ml}, \%$ of animals with detectable challenge virus; RT: Respiratory tract; URT and LRT: upper and lower RT, respectively; AGMs: African green monkeys; dpi: days post the last immunization; dpc: days post challenge.

\section{Potential Development of Chimeric Vaccines against HMPV}

As described, many studies have been performed with viral vectors (mainly paramyxoviruses) expressing pneumoviral proteins. Although the majority of those studies have focused on the development of anti-RSV vaccines, their results are an indicator of a potential for a successful vaccine candidate against HMPV. The efficacy of chimeric vaccines against HMPV can be potentially improved in many ways.

The immunogenicity of HMPV-F protein could be increased by codon optimization for human expression. This modification is based on the degeneracy of the genetic code and makes it possible to optimize the sequence in order to improve its expression in a specific expression system, for example, in human cells. Codon optimization along with amino acid substitutions that rendered the RSV-F amino acid sequence identical to the early passage of the original A2 isolate (HEK-substitutions) [111] improved the immunogenicity of RSV-F protein expressed by rB/HPIV3 by 5-fold, but not the protection against wt RSV infection [66]. Codon optimization alone conferred a 2.1-fold increase in RSV-F expression, and HEK-substitutions alone conferred a 2.4-fold increase. 
Although exogenous proteins are usually well-expressed on the surface of the cells infected by chimeric viruses, efficient incorporation of foreign proteins into the viral particles remains challenging. This can be achieved by TMCT domain swapping between the insert and the vector, as it has been demonstrated for the rB/HPIV3//RSV-F ${ }^{2 n d}$ virus [67]. Swapping of either the CT domain or TMCT domains increased the packaging efficiency 19-20-fold, reaching the level of RSV-F packaging into wt RSV virions. RSV-F ${ }^{(T M C T)}$ insert did not influence the incorporation of vector's HN protein but it decreased the packaging of its F protein by $50-60 \%$. TMCT modification did not influence viral replication in vitro, but it resulted in $10^{1}-10^{2}$ - and $10^{2}-10^{3}$-fold increase in attenuation in hamsters and rhesus macaques, respectively. Similar packaging improvement and restriction in hamsters were observed for rHPIV1- $\mathrm{C}^{\Delta 170}$ bearing RSV-F(TMCT) at the $1^{\text {st }}$ or the $2^{\text {nd }}$ gene position [155]. Interestingly, neither CT [208] nor TMCT domain exchange [207] improved packaging efficiency of RSV-F into VSV-GP particles, yet TMCT modification was necessary to efficiently express surface proteins of other viruses, for example, HIV-1 [212,213]. This proves that exchanging TMCT domains could be an attractive strategy to increase the incorporation of HMPV antigens into vector's particles, yet this modification can cause an additional attenuating effect on the chimeric virus and each combination of a vector with antigen requires individual design.

It has been demonstrated that the immunization with rB/HPIV3 expressing both RSV-F and G was more efficient than simultaneous immunization with two single-insert chimeras bearing either RSV-F or G [61]. It is supposed that this effect is due to interactions between these two surface glycoproteins that are closely associated one to another when expressed simultaneously within the same infected cell. Considering the structural similarities between RSV and HMPV, it might be presumed that the simultaneous expression of both HMPV-F and G proteins could have a beneficial effect on the efficacy of the vaccine, as it was also demonstrated for AMPV_C [189]. However, the study performed on virus-like particles (VLPs) expressing HMPV-F alone or along with the G protein showed that co-incorporation of the HMPV-G protein into VLP does not improve the immunogenicity conferred by the F protein [84]. Therefore, it is not likely that coexpression of HMPV-F and G could improve the vaccine's immunogenicity and other improvement strategies should be considered.

Another possible strategy for improving the design of anti-HMPV vaccines could be the expression of more than one copy of HMPV antigen. The HMPV virus expressing two additional copies of its F gene and one additional copy of its $G$ gene from the $1^{\text {st }}$ genomic position has been described [130]. The expression of $\mathrm{F}$ and $\mathrm{G}$ protein mRNA by this recombinant HMPV was increased more than 6-fold and 14-fold, respectively, compared to wt HMPV. The in vitro replication of this recombinant virus was approximately 7-times reduced comparing to wt HMPV, which is a relatively small reduction, considering the fact that the genome length of the virus was increased by $30 \%$. This study showed that adding additional copies of the ORF of HMPV-F or/and G could potentially increase the expression of its antigens also in the backbone of other vectors.

\section{Conclusions}

HMPV and RSV are important pediatric pathogens. Despite many years of research, no vaccine against either HMPV or RSV is currently available, underlining the need for novel solutions for vaccine design and/ or optimization of existing strategies. Generation of recombinant chimeric vaccines that protect against more than one pathogen is an advantageous and practical solution for elaborating a promising vaccine candidate. Many studies were performed on vaccines containing an antigen of RSV expressed by a heterologous virus, mainly the F protein, and some of these bivalent vaccines were advanced to clinical trials. Although the possibilities of generating chimeric vaccines against HMPV were less-explored than for RSV, numerous similarities between the two viruses can serve as a guide for the design of anti-HMPV vaccines. The antigens of HMPV and RSV were successfully expressed by various viral vectors, most of which belong to the Paramyxoviridae family. Notwithstanding that paramyxoviruses can readily express exogenous proteins from an added gene in their genome, many different factors condition the viability of a chimeric virus, the efficacy of exogene expression and the 
immunogenicity of a vaccine candidate. Not only does the choice of vector virus need be taken into consideration, various other aspects, namely, the positioning of an exogene in the vector's genome, the size and the type of an insert, and the possibility of integration of a foreign protein into the vector's particle, should be thoroughly considered. Numerous studies on the engineering of chimeric viruses indicate that each combination exogene-vector must be carefully designed and individually verified. Recombinant vaccine candidates against either HMPV or RSV that have been designed up to date indicate that using another virus to express HMPV antigens, or vice versa, can make it possible to overcome some major hurdles in HMPV vaccine development and obtain a good balance between immunogenicity and attenuation of a live recombinant vaccine.

Author Contributions: Writing-Original Draft Preparation, D.O.M.; Writing-Review \& Editing, M.-È.H., G.B.; Funding Acquisition, G.B. All authors have read and agreed to the published version of the manuscript.

Funding: This research was funded by CIHR \#273261.

Conflicts of Interest: The authors declare no conflict of interest.

\section{References}

1. GBD 2015 LRI Collaborators Estimates of the global, regional, and national morbidity, mortality, and aetiologies of lower respiratory tract infections in 195 countries: A systematic analysis for the Global Burden of Disease Study 2015. Lancet Infect. Dis. 2017, 17, 1133-1161. [CrossRef]

2. García-García, M.L.; Calvo, C.; Rey, C.; Díaz, B.; Molinero, M.D.; Pozo, F.; Casas, I. Human metapnuemovirus infections in hospitalized children and comparison with other respiratory viruses. 2005-2014 prospective study. PLoS ONE 2017, 12, e0173504.

3. Huck, B.; Scharf, G.; Neumann-Haefelin, D.; Puppe, W.; Weigl, J.; Falcone, V. Novel Human Metapneumovirus Sublineage. Emerg. Infect. Dis. 2006, 12, 147-150. [CrossRef] [PubMed]

4. Biacchesi, S.; Skiadopoulos, M.H.; Boivin, G.; Hanson, C.T.; Murphy, B.R.; Collins, P.L.; Buchholz, U.J. Genetic diversity between human metapneumovirus subgroups. Virology 2003, 315, 1-9. [CrossRef]

5. van den Hoogen, B.G.; Herfst, S.; Sprong, L.; Cane, P.A.; Forleo-Neto, E.; de Swart, R.L.; Osterhaus, A.D.M.E.; Fouchier, R.A.M. Antigenic and Genetic Variability of Human Metapneumoviruses. Emerg. Infect. Dis. 2004, 10, 658-666. [CrossRef] [PubMed]

6. Skiadopoulos, M.H.; Biacchesi, S.; Buchholz, U.J.; Riggs, J.M.; Surman, S.R.; Amaro-Carambot, E.; McAuliffe, J.M.; Elkins, W.R.; St. Claire, M.; Collins, P.L.; et al. The Two Major Human Metapneumovirus Genetic Lineages Are Highly Related Antigenically, and the Fusion (F) Protein Is a Major Contributor to This Antigenic Relatedness. J. Virol. 2004, 78, 6927-6937. [CrossRef] [PubMed]

7. Wei, H.-Y.; Tsao, K.-C.; Huang, C.-G.; Huang, Y.-C.; Lin, T.-Y. Clinical features of different genotypes/genogroups of human metapneumovirus in hospitalized children. J. Microbiol. Immunol. Infect. 2013, 46, 352-357. [CrossRef]

8. Juhasz, K.; Easton, A.J. Extensive Sequence Variation in the Attachment (G) Protein Gene of Avian Pneumovirus: Evidence for Two Distinct Subgroups. J. Gen. Virol. 1994, 75, 2873-2880. [CrossRef]

9. Seal, B.S. Matrix protein gene nucleotide and predicted amino acid sequence demonstrate that the first US avian pneumovirus isolate is distinct from European strains. Virus Res. 1998, 58, 45-52. [CrossRef]

10. Arnauld, C.; Bäyon-Auboyer, M.-H.; Eterradossi, N.; Toquin, D. Nucleotide sequences of the F, L and G protein genes of two non-A/non-B avian pneumoviruses (APV) reveal a novel APV subgroup. J. Gen. Virol. 2000, 81, 2723-2733.

11. van den Hoogen, B.G.; de Jong, J.C.; Groen, J.; Kuiken, T.; de Groot, R.; Fouchier, R.A.M.; Osterhaus, A.D.M.E. A newly discovered human pneumovirus isolated from young children with respiratory tract disease. Nat. Med. 2001, 7, 719-724. [CrossRef] [PubMed]

12. Moe, N.; Krokstad, S.; Stenseng, I.H.; Christensen, A.; Skanke, L.H.; Risnes, K.R.; Nordbø, S.A.; Døllner, H. Comparing Human Metapneumovirus and Respiratory Syncytial Virus: Viral Co-Detections, Genotypes and Risk Factors for Severe Disease. PLoS ONE 2017, 12, e0170200. [CrossRef] [PubMed]

13. Williams, J.V.; Edwards, K.M.; Weinberg, G.A.; Griffin, M.R.; Hall, C.B.; Zhu, Y.; Szilagyi, P.G.; Wang, C.K.; Yang, C.; Silva, D.; et al. Population-Based Incidence of Human Metapneumovirus Infection among Hospitalized Children. J. Infect. Dis. 2010, 201, 1890-1898. [CrossRef] [PubMed] 
14. Peiris, J.S.M.; Tang, W.-H.; Chan, K.-H.; Khong, P.-L.; Guan, Y.; Lau, Y.-L.; Chiu, S.S. Children with Respiratory Disease Associated with Metapneumovirus in Hong Kong. Emerg. Infect. Dis. 2003, 9, 628-633. [CrossRef] [PubMed]

15. Kusel, M.M.H.; de Klerk, N.H.; Kebadze, T.; Vohma, V.; Holt, P.G.; Johnston, S.L.; Sly, P.D. Early-life respiratory viral infections, atopic sensitization, and risk of subsequent development of persistent asthma. J. Allergy Clin. Immunol. 2007, 119, 1105-1110. [CrossRef]

16. Edwards, K.M.; Zhu, Y.; Griffin, M.R.; Weinberg, G.A.; Hall, C.B.; Szilagyi, P.G.; Staat, M.A.; Iwane, M.; Prill, M.M.; Williams, J.V. Burden of Human Metapneumovirus Infection in Young Children. N. Engl. J. Med. 2013, 368, 633-643. [CrossRef]

17. Bosis, S.; Esposito, S.; Niesters, H.G.M.; Crovari, P.; Osterhaus, A.D.M.E.; Principi, N. Impact of human metapneumovirus in childhood: Comparison with respiratory syncytial virus and influenza viruses. J. Med. Virol. 2005, 75, 101-104. [CrossRef]

18. Anderson, E.J.; Simões, E.A.F.; Buttery, J.P.; Dennehy, P.H.; Domachowske, J.B.; Jensen, K.; Lieberman, J.M.; Losonsky, G.A.; Yogev, R. Prevalence and Characteristics of Human Metapneumovirus Infection Among Hospitalized Children at High Risk for Severe Lower Respiratory Tract Infection. J. Pediatric Infect. Dis. Soc. 2012, 1, 212-222. [CrossRef]

19. Cattoir, L.; Vankeerberghen, A.; Boel, A.; Van Vaerenbergh, K.; De Beenhouwer, H. Epidemiology of RSV and hMPV in Belgium: A 10-year follow-up. Acta Clin. Belg. 2019, 74, 229-235. [CrossRef]

20. Glezen, W.P.; Taber, L.H.; Frank, A.L.; Kasel, J.A. Risk of primary infection and reinfection with respiratory syncytial virus. Am. J. Dis. Child. 1986, 140, 543-546. [CrossRef]

21. Leung, J.; Esper, F.; Weibel, C.; Kahn, J.S. Seroepidemiology of human metapneumovirus (hMPV) on the basis of a novel enzyme-linked immunosorbent assay utilizing hMPV fusion protein expressed in recombinant vesicular stomatitis virus. J. Clin. Microbiol. 2005, 43, 1213-1219. [CrossRef] [PubMed]

22. Falsey, A.R.; Erdman, D.; Anderson, L.J.; Walsh, E.E. Human Metapneumovirus Infections in Young and Elderly Adults. J. Infect. Dis. 2003, 187, 785-790. [CrossRef] [PubMed]

23. Englund, J.A.; Boeckh, M.; Kuypers, J.; Nichols, W.G.; Hackman, R.C.; Morrow, R.A.; Fredricks, D.N.; Corey, L. Brief Communication: Fatal Human Metapneumovirus Infection in Stem-Cell Transplant Recipients. Ann. Intern. Med. 2006, 144, 344. [CrossRef] [PubMed]

24. Mazur, N.I.; Higgins, D.; Nunes, M.C.; Melero, J.A.; Langedijk, A.C.; Horsley, N.; Buchholz, U.J.; Openshaw, P.J.; McLellan, J.S.; Englund, J.A.; et al. The respiratory syncytial virus vaccine landscape: Lessons from the graveyard and promising candidates. Lancet Infect. Dis. 2018, 18, e295-e311. [CrossRef]

25. Karron, R.A.; San Mateo, J.; Wanionek, K.; Collins, P.L.; Buchholz, U.J. Evaluation of a Live Attenuated Human Metapneumovirus Vaccine in Adults and Children. J. Pediatric Infect. Dis. Soc. 2018, 7, 86-89. [CrossRef]

26. Murphy, B.R.; Prince, G.A.; Walsh, E.E.; Kim, H.W.; Parrott, R.H.; Hemming, V.G.; Rodriguez, W.J.; Chanock, R.M. Dissociation between serum neutralizing and glycoprotein antibody responses of infants and children who received inactivated respiratory syncytial virus vaccine. J. Clin. Microbiol. 1986, 24, 197-202. [CrossRef]

27. Waris, M.E.; Tsou, C.; Erdman, D.D.; Zaki, S.R.; Anderson, L.J. Respiratory synctial virus infection in BALB/c mice previously immunized with formalin-inactivated virus induces enhanced pulmonary inflammatory response with a predominant Th2-like cytokine pattern. J. Virol. 1996, 70, 2852-2860. [CrossRef]

28. Kakuk, T.J.; Soike, K.; Brideau, R.J.; Zaya, R.M.; Cole, S.L.; Zhang, J.-Y.; Roberts, E.D.; Wells, P.A.; Wathen, M.W. A Human Respiratory Syncytial Virus (RSV) Primate Model of Enhanced Pulmonary Pathology Induced with a Formalin-Inactivated RSV Vaccine but Not a Recombinant FG Subunit Vaccine. J. Infect. Dis. 1993, 167, 553-561. [CrossRef]

29. Porter, D.D.; Prince, G.A.; Yim, K.C.; Curtis, S.J. Vaccine-enhanced respiratory syncytial virus disease in cotton rats following immunization with Lot 100 or a newly prepared reference vaccine. J. Gen. Virol. 2001, $82,2881-2888$.

30. Gershwin, L.J.; Schelegle, E.S.; Gunther, R.A.; Anderson, M.L.; Woolums, A.R.; Larochelle, D.R.; Boyle, G.A.; Friebertshauser, K.E.; Singer, R.S. A bovine model of vaccine enhanced respiratory syncytial virus pathophysiology. Vaccine 1998, 16, 1225-1236. [CrossRef] 
31. Yim, K.C.; Cragin, R.P.; Boukhvalova, M.S.; Blanco, J.C.G.; Hamlin, M.-È; Boivin, G.; Porter, D.D.; Prince, G.A. Human metapneumovirus: Enhanced pulmonary disease in cotton rats immunized with formalin-inactivated virus vaccine and challenged. Vaccine 2007, 25, 5034-5040. [CrossRef] [PubMed]

32. Hamelin, M.-E.; Couture, C.; Sackett, M.K.; Boivin, G. Enhanced lung disease and Th2 response following human metapneumovirus infection in mice immunized with the inactivated virus. J. Gen. Virol. 2007, 88, 3391-3400. [CrossRef] [PubMed]

33. Hall, C.B.; Walsh, E.E.; Long, C.E.; Schnabel, K.C. Immunity to and frequency of reinfection with respiratory syncytial virus. J. Infect. Dis. 1991, 163, 693-698. [CrossRef] [PubMed]

34. Alvarez, R.; Tripp, R.A. The Immune Response to Human Metapneumovirus Is Associated with Aberrant Immunity and Impaired Virus Clearance in BALB/c Mice. J. Virol. 2005, 79, 5971-5978. [CrossRef]

35. Valarcher, J.-F.; Furze, J.; Wyld, S.; Cook, R.; Conzelmann, K.-K.; Taylor, G. Role of alpha/beta interferons in the attenuation and immunogenicity of recombinant bovine respiratory syncytial viruses lacking NS proteins. J. Virol. 2003, 77, 8426-8439. [CrossRef] [PubMed]

36. Schlender, J.; Bossert, B.; Buchholz, U.; Conzelmann, K.K. Bovine respiratory syncytial virus nonstructural proteins NS1 and NS2 cooperatively antagonize alpha/beta interferon-induced antiviral response. J. Virol. 2000, 74, 8234-8242. [CrossRef]

37. Spann, K.M.; Tran, K.-C.; Chi, B.; Rabin, R.L.; Collins, P.L. Suppression of the induction of alpha, beta, and lambda interferons by the NS1 and NS2 proteins of human respiratory syncytial virus in human epithelial cells and macrophages [corrected]. J. Virol. 2004, 78, 4363-4369. [CrossRef]

38. Bao, X.; Liu, T.; Shan, Y.; Li, K.; Garofalo, R.P.; Casola, A. Human metapneumovirus glycoprotein G inhibits innate immune responses. Plos Pathog. 2008, 4, e1000077. [CrossRef]

39. Cheemarla, N.R.; Guerrero-Plata, A. Human Metapneumovirus Attachment Protein Contributes to Neutrophil Recruitment into the Airways of Infected Mice. Viruses 2017, 9, 310. [CrossRef]

40. Bao, X.; Kolli, D.; Liu, T.; Shan, Y.; Garofalo, R.P.; Casola, A. Human Metapneumovirus Small Hydrophobic Protein Inhibits NF- B Transcriptional Activity. J. Virol. 2008, 82, 8224-8229. [CrossRef]

41. Ren, J.; Wang, Q.; Kolli, D.; Prusak, D.J.; Tseng, C.-T.K.; Chen, Z.J.; Li, K.; Wood, T.G.; Bao, X. Human Metapneumovirus M2-2 Protein Inhibits Innate Cellular Signaling by Targeting MAVS. J. Virol. 2012, 86, 13049-13061. [CrossRef] [PubMed]

42. Ren, J.; Liu, G.; Go, J.; Kolli, D.; Zhang, G.; Bao, X. Human Metapneumovirus M2-2 Protein Inhibits Innate Immune Response in Monocyte-Derived Dendritic Cells. PLoS ONE 2014, 9, e91865. [CrossRef] [PubMed]

43. Alvarez, R.; Harrod, K.S.; Shieh, W.-J.; Zaki, S.; Tripp, R.A. Human Metapneumovirus Persists in BALB/c Mice despite the Presence of Neutralizing Antibodies. J. Virol. 2004, 78, 14003-14011. [CrossRef] [PubMed]

44. Mejías, A.; Chávez-Bueno, S.; Gómez, A.M.; Somers, C.; Estripeaut, D.; Torres, J.P.; Jafri, H.S.; Ramilo, O. Respiratory Syncytial Virus Persistence: Evidence in the Mouse Model. Pediatric Infect. Dis. J. 2008, 27, S60-S62. [CrossRef]

45. Schwarze, J.; O’Donnell, D.R.; Rohwedder, A.; Openshaw, P.J.M. Latency and Persistence of Respiratory Syncytial Virus Despite T Cell Immunity. Am. J. Respir. Crit. Care Med. 2004, 169, 801-805. [CrossRef]

46. Dakhama, A.; Vitalis, T.Z.; Hegel, R.G. Persistence of respiratory syncytial virus (RSV) infection and development of RSV-specific IgG1 response in a guinea-pig model of acute brochiolitis. Eur. Respir. J. 1997, 10, 20-26. [CrossRef]

47. Englund, J.A. Passive protection against respiratory syncytial virus disease in infants: The role of maternal antibody. Pediatric Infect. Dis. J. 1994, 13, 449-453. [CrossRef]

48. van Erp, E.A.; van Kasteren, P.B.; Guichelaar, T.; Ahout, I.M.L.; de Haan, C.A.M.; Luytjes, W.; Ferwerda, G.; Wicht, O. In Vitro Enhancement of Respiratory Syncytial Virus Infection by Maternal Antibodies Does Not Explain Disease Severity in Infants. J. Virol. 2017, 91, e00851-17. [CrossRef]

49. Patton, K.; Aslam, S.; Shambaugh, C.; Lin, R.; Heeke, D.; Frantz, C.; Zuo, F.; Esser, M.T.; Paliard, X.; Lambert, S.L. Enhanced immunogenicity of a respiratory syncytial virus (RSV) F subunit vaccine formulated with the adjuvant GLA-SE in cynomolgus macaques. Vaccine 2015, 33, 4472-4478. [CrossRef]

50. Cseke, G.; Wright, D.W.; Tollefson, S.J.; Johnson, J.E.; Crowe, J.E.; Williams, J.V. Human Metapneumovirus Fusion Protein Vaccines That Are Immunogenic and Protective in Cotton Rats. J. Virol. 2007, 81, 698-707. [CrossRef] 
51. Smith, T.R.F.; Schultheis, K.; Morrow, M.P.; Kraynyak, K.A.; McCoy, J.R.; Yim, K.C.; Muthumani, K.; Humeau, L.; Weiner, D.B.; Sardesai, N.Y.; et al. Development of an intradermal DNA vaccine delivery strategy to achieve single-dose immunity against respiratory syncytial virus. Vaccine 2017, 35, 2840-2847. [CrossRef] [PubMed]

52. Ma, Y.; Jiao, Y.-Y.; Yu, Y.-Z.; Jiang, N.; Hua, Y.; Zhang, X.-J.; Fu, Y.-H.; Peng, X.-L.; Zheng, Y.-P.; Anderson, L.; et al. A Built-In CpG Adjuvant in RSV F Protein DNA Vaccine Drives a Th1 Polarized and Enhanced Protective Immune Response. Viruses 2018, 10, 38. [CrossRef] [PubMed]

53. Shaw, C.; Lee, H.; Knightly, C.; Kalidindi, S.; Zaks, T.; Smolenov, I.; Panther, L. 2754. Phase 1 Trial of an mRNA-Based Combination Vaccine Against hMPV and PIV3. Open Forum Infect. Dis. 2019, 6, S970. [CrossRef]

54. Skiadopoulos, M.H.; Biacchesi, S.; Buchholz, U.J.; Amaro-Carambot, E.; Surman, S.R.; Collins, P.L.; Murphy, B.R. Individual contributions of the human metapneumovirus F, G, and SH surface glycoproteins to the induction of neutralizing antibodies and protective immunity. Virology 2006, 345, 492-501. [CrossRef] [PubMed]

55. Melero, J.A.; Mas, V. The Pneumovirinae fusion (F) protein: A common target for vaccines and antivirals. Virus Res. 2015, 209, 128-135. [CrossRef]

56. Ryder, A.B.; Tollefson, S.J.; Podsiad, A.B.; Johnson, J.E.; Williams, J.V. Soluble recombinant human metapneumovirus $\mathrm{G}$ protein is immunogenic but not protective. Vaccine 2010, 28, 4145-4152. [CrossRef]

57. Biacchesi, S.; Skiadopoulos, M.H.; Yang, L.; Lamirande, E.W.; Tran, K.C.; Murphy, B.R.; Collins, P.L.; Buchholz, U.J. Recombinant Human Metapneumovirus Lacking the Small Hydrophobic SH and/or Attachment G Glycoprotein: Deletion of G Yields a Promising Vaccine Candidate. J. Virol. 2004, 78, 12877-12887. [CrossRef]

58. Connors, M.; Collins, P.L.; Firestone, C.Y.; Murphy, B.R. Respiratory syncytial virus (RSV) F, G, M2 (22K), and $\mathrm{N}$ proteins each induce resistance to RSV challenge, but resistance induced by M2 and N proteins is relatively short-lived. J. Virol. 1991, 65, 1634-1637. [CrossRef]

59. Olmsted, R.A.; Elango, N.; Prince, G.A.; Murphy, B.R.; Johnson, P.R.; Moss, B.; Chanock, R.M.; Collins, P.L. Expression of the $\mathrm{F}$ glycoprotein of respiratory syncytial virus by a recombinant vaccinia virus: Comparison of the individual contributions of the F and G glycoproteins to host immunity. Proc. Natl. Acad. Sci. USA 1986, 83, 7462-7466. [CrossRef]

60. Schmidt, A.C.; McAuliffe, J.M.; Murphy, B.R.; Collins, P.L. Recombinant Bovine/Human Parainfluenza Virus Type 3 (B/HPIV3) Expressing the Respiratory Syncytial Virus (RSV) G and F Proteins Can Be Used to Achieve Simultaneous Mucosal Immunization against RSV and HPIV3. J. Virol. 2001, 75, 4594-4603. [CrossRef]

61. Schmidt, A.C.; Wenzke, D.R.; McAuliffe, J.M.; St Claire, M.; Elkins, W.R.; Murphy, B.R.; Collins, P.L. Mucosal Immunization of Rhesus Monkeys against Respiratory Syncytial Virus Subgroups A and B and Human Parainfluenza Virus Type 3 by Using a Live cDNA-Derived Vaccine Based on a Host Range-Attenuated Bovine Parainfluenza Virus Type 3 Vector Backbone. J. Virol. 2002, 76, 1089-1099. [CrossRef] [PubMed]

62. Li, C.; Zhou, X.; Zhong, Y.; Li, C.; Dong, A.; He, Z.; Zhang, S.; Wang, B. A Recombinant G Protein Plus Cyclosporine A-Based Respiratory Syncytial Virus Vaccine Elicits Humoral and Regulatory T Cell Responses against Infection without Vaccine-Enhanced Disease. J. Immunol. 2016, 196, 1721-1731. [CrossRef] [PubMed]

63. Fuentes, S.; Klenow, L.; Golding, H.; Khurana, S. Preclinical evaluation of bacterially produced RSV-G protein vaccine: Strong protection against RSV challenge in cotton rat model. Sci. Rep. 2017, 7, 1-13. [CrossRef] [PubMed]

64. Zhang, S.; Zhao, G.; Su, C.; Li, C.; Zhou, X.; Zhao, W.; Zhong, Y.; He, Z.; Peng, H.; Dong, A.; et al. Neonatal priming and infancy boosting with a novel respiratory syncytial virus vaccine induces protective immune responses without concomitant respiratory disease upon RSV challenge. Hum. Vaccines Immunother. 2019, 1-9. [CrossRef] [PubMed]

65. McLellan, J.S.; Chen, M.; Joyce, M.G.; Sastry, M.; Stewart-Jones, G.B.E.; Yang, Y.; Zhang, B.; Chen, L.; Srivatsan, S.; Zheng, A.; et al. Structure-Based Design of a Fusion Glycoprotein Vaccine for Respiratory Syncytial Virus. Science 2013, 342, 592-598. [CrossRef]

66. Liang, B.; Surman, S.; Amaro-Carambot, E.; Kabatova, B.; Mackow, N.; Lingemann, M.; Yang, L.; McLellan, J.S.; Graham, B.S.; Kwong, P.D.; et al. Enhanced Neutralizing Antibody Response Induced by Respiratory Syncytial Virus Prefusion F Protein Expressed by a Vaccine Candidate. J. Virol. 2015, 89, 9499-9510. [CrossRef] 
67. Liang, B.; Ngwuta, J.O.; Herbert, R.; Swerczek, J.; Dorward, D.W.; Amaro-Carambot, E.; Mackow, N.; Kabatova, B.; Lingemann, M.; Surman, S.; et al. Packaging and Prefusion Stabilization Separately and Additively Increase the Quantity and Quality of Respiratory Syncytial Virus (RSV)-Neutralizing Antibodies Induced by an RSV Fusion Protein Expressed by a Parainfluenza Virus Vector. J. Virol. 2016, 90, 10022-10038. [CrossRef]

68. Herfst, S.; Schrauwen, E.J.A.; de Graaf, M.; van Amerongen, G.; van den Hoogen, B.G.; de Swart, R.L.; Osterhaus, A.D.M.E.; Fouchier, R.A.M. Immunogenicity and efficacy of two candidate human metapneumovirus vaccines in cynomolgus macaques. Vaccine 2008, 26, 4224-4230. [CrossRef]

69. Battles, M.B.; Más, V.; Olmedillas, E.; Cano, O.; Vázquez, M.; Rodríguez, L.; Melero, J.A.; McLellan, J.S. Structure and immunogenicity of pre-fusion-stabilized human metapneumovirus $\mathrm{F}$ glycoprotein. Nat. Commun. 2017, 8,1-11. [CrossRef]

70. Pilaev, M.; Shen, Y.; Carbonneau, J.; Venable, M.-C.; Rhéaume, C.; Lavigne, S.; Couture, C.; Guarné, A.; Hamelin, M.-E.; Boivin, G. Evaluation of pre- and post-fusion Human metapneumovirus F proteins as subunit vaccine candidates in mice. Vaccine 2020, in press. [CrossRef]

71. Corti, D.; Bianchi, S.; Vanzetta, F.; Minola, A.; Perez, L.; Agatic, G.; Guarino, B.; Silacci, C.; Marcandalli, J.; Marsland, B.J.; et al. Cross-neutralization of four paramyxoviruses by a human monoclonal antibody. Nature 2013, 501, 439-443. [CrossRef] [PubMed]

72. Schuster, J.E.; Cox, R.G.; Hastings, A.K.; Boyd, K.L.; Wadia, J.; Chen, Z.; Burton, D.R.; Williamson, R.A.; Williams, J.V. A Broadly Neutralizing Human Monoclonal Antibody Exhibits In Vivo Efficacy Against Both Human Metapneumovirus and Respiratory Syncytial Virus. J. Infect. Dis. 2015, 211, 216-225. [CrossRef] [PubMed]

73. Wen, X.; Mousa, J.J.; Bates, J.T.; Lamb, R.A.; Crowe, J.E.; Jardetzky, T.S. Structural basis for antibody cross-neutralization of respiratory syncytial virus and human metapneumovirus. Nat. Microbiol. 2017, 2, 1-7. [CrossRef] [PubMed]

74. Xiao, X.; Tang, A.; Cox, K.S.; Wen, Z.; Callahan, C.; Sullivan, N.L.; Nahas, D.D.; Cosmi, S.; Galli, J.D.; Minnier, M.; et al. Characterization of potent RSV neutralizing antibodies isolated from human memory B cells and identification of diverse RSV/hMPV cross-neutralizing epitopes. mAbs 2019, 11, 1415-1427. [CrossRef] [PubMed]

75. Mousa, J.J.; Binshtein, E.; Human, S.; Fong, R.H.; Alvarado, G.; Doranz, B.J.; Moore, M.L.; Ohi, M.D.; Crowe, J.E. Human antibody recognition of antigenic site IV on Pneumovirus fusion proteins. PLoS Pathog. 2018, 14, e1006837. [CrossRef]

76. Wen, X.; Pickens, J.; Mousa, J.J.; Leser, G.P.; Lamb, R.A.; Crowe, J.E.; Jardetzky, T.S. A Chimeric Pneumovirus Fusion Protein Carrying Neutralizing Epitopes of Both MPV and RSV. PLoS ONE 2016, 11, e0155917. [CrossRef] [PubMed]

77. Olmedillas, E.; Cano, O.; Martínez, I.; Luque, D.; Terrón, M.C.; McLellan, J.S.; Melero, J.A.; Más, V. Chimeric Pneumoviridae fusion proteins as immunogens to induce cross-neutralizing antibody responses. Embo. Mol. Med. 2018, 10, 175-187. [CrossRef]

78. Smith, G.; Raghunandan, R.; Wu, Y.; Liu, Y.; Massare, M.; Nathan, M.; Zhou, B.; Lu, H.; Boddapati, S.; Li, J.; et al. Respiratory Syncytial Virus Fusion Glycoprotein Expressed in Insect Cells Form Protein Nanoparticles That Induce Protective Immunity in Cotton Rats. PLoS ONE 2012, 7, e50852. [CrossRef]

79. Glenn, G.M.; Fries, L.F.; Thomas, D.N.; Smith, G.; Kpamegan, E.; Lu, H.; Flyer, D.; Jani, D.; Hickman, S.P.; Piedra, P.A. A Randomized, Blinded, Controlled, Dose-Ranging Study of a Respiratory Syncytial Virus Recombinant Fusion (F) Nanoparticle Vaccine in Healthy Women of Childbearing Age. J. Infect. Dis. 2016, 213, 411-422. [CrossRef]

80. Patel, N.; Massare, M.J.; Tian, J.-H.; Guebre-Xabier, M.; Lu, H.; Zhou, H.; Maynard, E.; Scott, D.; Ellingsworth, L.; Glenn, G.; et al. Respiratory syncytial virus prefusogenic fusion (F) protein nanoparticle vaccine: Structure, antigenic profile, immunogenicity, and protection. Vaccine 2019, 37, 6112-6124. [CrossRef]

81. Novavax Announces Topline Results from Phase 3 PrepareTM Trial of ResVaxTM for Prevention of RSV Disease in Infants via Maternal Immunization. 2019. Available online: https://www.nasdaq.com/pressrelease/novavax-announces-topline-results-phase-3-preparetm-trial-resvaxtm-prevention-rsv (accessed on 2 November 2019). 
82. Loo, L.; Jumat, M.; Fu, Y.; Ayi, T.; Wong, P.; Tee, N.W.; Tan, B.; Sugrue, R.J. Evidence for the interaction of the human metapneumovirus G and F proteins during virus-like particle formation. Virol. J. 2013, 10, 294. [CrossRef] [PubMed]

83. Wen, S.C.; Schuster, J.E.; Gilchuk, P.; Boyd, K.L.; Joyce, S.; Williams, J.V. Lung CD8 + T Cell Impairment Occurs during Human Metapneumovirus Infection despite Virus-Like Particle Induction of Functional CD8 + T Cells. J. Virol. 2015, 89, 8713-8726. [CrossRef] [PubMed]

84. Lévy, C.; Aerts, L.; Hamelin, M.-Ė.; Granier, C.; Szécsi, J.; Lavillette, D.; Boivin, G.; Cosset, F.-L. Virus-like particle vaccine induces cross-protection against human metapneumovirus infections in mice. Vaccine 2013, 31, 2778-2785. [CrossRef] [PubMed]

85. Cox, R.G.; Erickson, J.J.; Hastings, A.K.; Becker, J.C.; Johnson, M.; Craven, R.E.; Tollefson, S.J.; Boyd, K.L.; Williams, J.V. Human Metapneumovirus Virus-Like Particles Induce Protective B and T Cell Responses in a Mouse Model. J. Virol. 2014, 88, 6368-6379. [CrossRef]

86. McGinnes, L.W.; Gravel, K.A.; Finberg, R.W.; Kurt-Jones, E.A.; Massare, M.J.; Smith, G.; Schmidt, M.R.; Morrison, T.G. Assembly and Immunological Properties of Newcastle Disease Virus-Like Particles Containing the Respiratory Syncytial Virus F and G Proteins. J. Virol. 2011, 85, 366-377. [CrossRef]

87. Murawski, M.R.; McGinnes, L.W.; Finberg, R.W.; Kurt-Jones, E.A.; Massare, M.J.; Smith, G.; Heaton, P.M.; Fraire, A.E.; Morrison, T.G. Newcastle Disease Virus-Like Particles Containing Respiratory Syncytial Virus G Protein Induced Protection in BALB/c Mice, with No Evidence of Immunopathology. J. Virol. 2010, 84, 1110-1123. [CrossRef]

88. Quan, F.-S.; Kim, Y.; Lee, S.; Yi, H.; Kang, S.-M.; Bozja, J.; Moore, M.L.; Compans, R.W. Viruslike Particle Vaccine Induces Protection Against Respiratory Syncytial Virus Infection in Mice. J. Infect. Dis. 2011, 204, 987-995. [CrossRef]

89. Hwang, H.S.; Kwon, Y.-M.; Lee, J.S.; Yoo, S.-E.; Lee, Y.-N.; Ko, E.-J.; Kim, M.-C.; Cho, M.-K.; Lee, Y.-T.; Jung, Y.-J.; et al. Co-immunization with virus-like particle and DNA vaccines induces protection against respiratory syncytial virus infection and bronchiolitis. Antivir. Res. 2014, 110, 115-123. [CrossRef]

90. Lee, S.; Quan, F.-S.; Kwon, Y.; Sakamoto, K.; Kang, S.-M.; Compans, R.W.; Moore, M.L. Additive protection induced by mixed virus-like particles presenting respiratory syncytial virus fusion or attachment glycoproteins. Antivir. Res. 2014, 111, 129-135. [CrossRef]

91. Raghunandan, R.; Lu, H.; Zhou, B.; Xabier, M.G.; Massare, M.J.; Flyer, D.C.; Fries, L.F.; Smith, G.E.; Glenn, G.M. An insect cell derived respiratory syncytial virus (RSV) F nanoparticle vaccine induces antigenic site II antibodies and protects against RSV challenge in cotton rats by active and passive immunization. Vaccine 2014, 32, 6485-6492. [CrossRef]

92. Ko, E.-J.; Kwon, Y.-M.; Lee, J.S.; Hwang, H.S.; Yoo, S.-E.; Lee, Y.-N.; Lee, Y.-T.; Kim, M.-C.; Cho, M.K.; Lee, Y.R.; et al. Virus-like nanoparticle and DNA vaccination confers protection against respiratory syncytial virus by modulating innate and adaptive immune cells. Nanomed. Nanotechnol. Biol. Med. 2015, 11,99-108. [CrossRef] [PubMed]

93. McGinnes Cullen, L.; Schmidt, M.R.; Kenward, S.A.; Woodland, R.T.; Morrison, T.G. Murine Immune Responses to Virus-Like Particle-Associated Pre- and Postfusion Forms of the Respiratory Syncytial Virus F Protein. J. Virol. 2015, 89, 6835-6847. [CrossRef] [PubMed]

94. Walpita, P.; Johns, L.M.; Tandon, R.; Moore, M.L. Mammalian Cell-Derived Respiratory Syncytial Virus-Like Particles Protect the Lower as well as the Upper Respiratory Tract. PLoS ONE 2015, 10, e0130755. [CrossRef] [PubMed]

95. Kim, K.-H.; Lee, Y.-T.; Hwang, H.S.; Kwon, Y.-M.; Kim, M.-C.; Ko, E.-J.; Lee, J.S.; Lee, Y.; Kang, S.-M. Virus-Like Particle Vaccine Containing the F Protein of Respiratory Syncytial Virus Confers Protection without Pulmonary Disease by Modulating Specific Subsets of Dendritic Cells and Effector T Cells. J. Virol. 2015, 89, 11692-11705. [CrossRef] [PubMed]

96. Cimica, V.; Boigard, H.; Bhatia, B.; Fallon, J.T.; Alimova, A.; Gottlieb, P.; Galarza, J.M. Novel Respiratory Syncytial Virus-Like Particle Vaccine Composed of the Postfusion and Prefusion Conformations of the F Glycoprotein. Clin. Vaccine Immunol. 2016, 23, 451-459. [CrossRef]

97. Hwang, H.S.; Lee, Y.-T.; Kim, K.-H.; Park, S.; Kwon, Y.-M.; Lee, Y.; Ko, E.-J.; Jung, Y.-J.; Lee, J.S.; Kim, Y.-J.; et al. Combined virus-like particle and fusion protein-encoding DNA vaccination of cotton rats induces protection against respiratory syncytial virus without causing vaccine-enhanced disease. Virology 2016, 494, 215-224. [CrossRef] 
98. Hwang, H.S.; Lee, Y.-T.; Kim, K.-H.; Ko, E.-J.; Lee, Y.; Kwon, Y.-M.; Kang, S.-M. Virus-like particle vaccine primes immune responses preventing inactivated-virus vaccine-enhanced disease against respiratory syncytial virus. Virology 2017, 511, 142-151. [CrossRef]

99. Hwang, H.S.; Kim, K.-H.; Lee, Y.; Lee, Y.-T.; Ko, E.-J.; Park, S.; Lee, J.S.; Lee, B.; Kwon, Y.-M.; Moore, M.L.; et al. Virus-like particle vaccines containing $\mathrm{F}$ or $\mathrm{F}$ and $\mathrm{G}$ proteins confer protection against respiratory syncytial virus without pulmonary inflammation in cotton rats. Hum. Vaccines Immunother. 2017, 13, 1031-1039. [CrossRef]

100. Kim, A.-R.; Lee, D.-H.; Lee, S.-H.; Rubino, I.; Choi, H.-J.; Quan, F.-S. Protection induced by virus-like particle vaccine containing tandem repeat gene of respiratory syncytial virus G protein. PLoS ONE 2018, 13, e0191277. [CrossRef]

101. Lee, Y.; Lee, Y.-T.; Ko, E.-J.; Kim, K.-H.; Hwang, H.S.; Park, S.; Kwon, Y.-M.; Kang, S.M. Soluble F proteins exacerbate pulmonary histopathology after vaccination upon respiratory syncytial virus challenge but not when presented on virus-like particles. Hum. Vaccines Immunother. 2017, 13, 2594-2605. [CrossRef]

102. Blanco, J.C.G.; Pletneva, L.M.; McGinnes-Cullen, L.; Otoa, R.O.; Patel, M.C.; Fernando, L.R.; Boukhvalova, M.S.; Morrison, T.G. Efficacy of a respiratory syncytial virus vaccine candidate in a maternal immunization model. Nat. Commun. 2018, 9, 1-10. [CrossRef] [PubMed]

103. Gilbert, B.E.; Patel, N.; Lu, H.; Liu, Y.; Guebre-Xabier, M.; Piedra, P.A.; Glenn, G.; Ellingsworth, L.; Smith, G. Respiratory syncytial virus fusion nanoparticle vaccine immune responses target multiple neutralizing epitopes that contribute to protection against wild-type and palivizumab-resistant mutant virus challenge. Vaccine 2018, 36, 8069-8078. [CrossRef] [PubMed]

104. McGinnes Cullen, L.; Schmidt, M.R.; Morrison, T.G. Effect of Previous Respiratory Syncytial Virus Infection on Murine Immune Responses to F and G Protein-Containing Virus-Like Particles. J. Virol. 2019, 93, e00087-19. [CrossRef] [PubMed]

105. Cullen, L.; Schmidt, M.; Torres, G.; Capoferri, A.; Morrison, T. Comparison of Immune Responses to Different Versions of VLP Associated Stabilized RSV Pre-Fusion F Protein. Vaccines 2019, 7, 21. [CrossRef] [PubMed]

106. Buchholz, U.J.; Nagashima, K.; Murphy, B.R.; Collins, P.L. Live vaccines for human metapneumovirus designed by reverse genetics. Expert Rev. Vaccines 2006, 5, 695-706. [CrossRef] [PubMed]

107. Bull, J.J. Evolutionary reversion of live viral vaccines: Can genetic engineering subdue it? Virus Evol. 2015, 1, vev005. [CrossRef]

108. Randolph, V.B.; Kandis, M.; Stemler-Higgins, P.; Kennelly, M.S.; McMullen, Y.M.; Speelman, D.J.; Weeks-Levy, C. Attenuated temperature-sensitive respiratory syncytial virus mutants generated by cold adaptation. Virus Res. 1994, 33, 241-259. [CrossRef]

109. Crowe, J. Cold-passaged, temperature-sensitive mutants of human respiratory syncytial virus (RSV) are highly attenuated, immunogenic, and protective in seronegative chimpanzees, even when RSV antibodies are infused shortly before immunization. Vaccine 1995, 13, 847-855. [CrossRef]

110. Juhasz, K.; Whitehead, S.S.; Bui, P.T.; Biggs, J.M.; Crowe, J.E.; Boulanger, C.A.; Collins, P.L.; Murphy, B.R. The temperature-sensitive (ts) phenotype of a cold-passaged ( $\mathrm{cp}$ ) live attenuated respiratory syncytial virus vaccine candidate, designated cpts530, results from a single amino acid substitution in the L protein. J. Virol. 1997, 71, 5814-5819. [CrossRef]

111. Whitehead, S.S.; Juhasz, K.; Firestone, C.Y.; Collins, P.L.; Murphy, B.R. Recombinant respiratory syncytial virus (RSV) bearing a set of mutations from cold-passaged RSV is attenuated in chimpanzees. J. Virol. 1998, 72, 4467-4471. [CrossRef]

112. Herfst, S.; de Graaf, M.; Schrauwen, E.J.A.; Sprong, L.; Hussain, K.; van den Hoogen, B.G.; Osterhaus, A.D.M.E.; Fouchier, R.A.M. Generation of temperature-sensitive human metapneumovirus strains that provide protective immunity in hamsters. J. Gen. Virol. 2008, 89, 1553-1562. [CrossRef] [PubMed]

113. Herfst, S.; de Graaf, M.; Schickli, J.H.; Tang, R.S.; Kaur, J.; Yang, C.-F.; Spaete, R.R.; Haller, A.A.; van den Hoogen, B.G.; Osterhaus, A.D.M.E.; et al. Recovery of Human Metapneumovirus Genetic Lineages A and B from Cloned cDNA. J. Virol. 2004, 78, 8264-8270. [CrossRef] [PubMed]

114. Hu, B.; Jiang, J.; Zhan, J.; Li, G.; Jiang, Y.; Guan, X.; Chen, Y.; Fang, Z. Development of a reverse genetics system for respiratory syncytial virus long strain and an immunogenicity study of the recombinant virus. Virol. J. 2014, 11, 142. [CrossRef] [PubMed] 
115. Karron, R.A.; Luongo, C.; Thumar, B.; Loehr, K.M.; Englund, J.A.; Collins, P.L.; Buchholz, U.J. A gene deletion that up-regulates viral gene expression yields an attenuated RSV vaccine with improved antibody responses in children. Sci. Transl. Med. 2015, 7, 312ra175. [CrossRef] [PubMed]

116. Pham, Q.N.; Biacchesi, S.; Skiadopoulos, M.H.; Murphy, B.R.; Collins, P.L.; Buchholz, U.J. Chimeric Recombinant Human Metapneumoviruses with the Nucleoprotein or Phosphoprotein Open Reading Frame Replaced by That of Avian Metapneumovirus Exhibit Improved Growth In Vitro and Attenuation In Vivo. J. Virol. 2005, 79, 15114-15122. [CrossRef] [PubMed]

117. Phan, T.; Ren, J.; Bao, X. Recent vaccine development for human metapneumovirus. J. Gen. Virol. 2015, 96, 1515-1520.

118. Anderson, L.J.; Dormitzer, P.R.; Nokes, D.J.; Rappuoli, R.; Roca, A.; Graham, B.S. Strategic priorities for respiratory syncytial virus (RSV) vaccine development. Vaccine 2013, 31, B209-B215. [CrossRef]

119. Tang, R.S.; MacPhail, M.; Schickli, J.H.; Kaur, J.; Robinson, C.L.; Lawlor, H.A.; Guzzetta, J.M.; Spaete, R.R.; Haller, A.A. Parainfluenza Virus Type 3 Expressing the Native or Soluble Fusion (F) Protein of Respiratory Syncytial Virus (RSV) Confers Protection from RSV Infection in African Green Monkeys. J. Virol. 2004, 78, 11198-11207. [CrossRef]

120. Tang, R.S.; Mahmood, K.; Macphail, M.; Guzzetta, J.M.; Haller, A.A.; Liu, H.; Kaur, J.; Lawlor, H.A.; Stillman, E.A.; Schickli, J.H.; et al. A host-range restricted parainfluenza virus type 3 (PIV3) expressing the human metapneumovirus (hMPV) fusion protein elicits protective immunity in African green monkeys. Vaccine 2005, 23, 1657-1667. [CrossRef]

121. Fields, B.N.; Knipe, D.M.; Howley, P.M. Fields Virology; Wolters Kluwer/Lippincott Williams \& Wilkins Health: Philadelphia, PA, USA, 2013; ISBN 9781451105636.

122. Bukreyev, A.; Skiadopoulos, M.H.; Murphy, B.R.; Collins, P.L. Nonsegmented Negative-Strand Viruses as Vaccine Vectors. J. Virol. 2006, 80, 10293-10306. [CrossRef]

123. Spann, K.M.; Collins, P.L.; Teng, M.N. Genetic recombination during coinfection of two mutants of human respiratory syncytial virus. J. Virol. 2003, 77, 11201-11211. [CrossRef] [PubMed]

124. Chare, E.R.; Gould, E.A.; Holmes, E.C. Phylogenetic analysis reveals a low rate of homologous recombination in negative-sense RNA viruses. J. Gen. Virol. 2003, 84, 2691-2703. [CrossRef] [PubMed]

125. Skiadopoulos, M.H.; Surman, S.R.; Riggs, J.M.; Örvell, C.; Collins, P.L.; Murphy, B.R. Evaluation of the Replication and Immunogenicity of Recombinant Human Parainfluenza Virus Type 3 Vectors Expressing up to Three Foreign Glycoproteins. Virology 2002, 297, 136-152. [CrossRef] [PubMed]

126. Kawaoka, Y. Biology of Negative Strand RNA Viruses: The Power of Reverse Genetics; Springer Science \& Business Media: Berlin, Germany, 2013; ISBN 978-3-662-06099-5.

127. Beaty, S.M.; Park, A.; Won, S.T.; Hong, P.; Lyons, M.; Vigant, F.; Freiberg, A.N.; tenOever, B.R.; Duprex, W.P.; Lee, B. Efficient and Robust Paramyxoviridae Reverse Genetics Systems. mSphere 2017, 2, e0376-16. [CrossRef] [PubMed]

128. Yu, Q.; Hardy, R.W.; Wertz, G.W. Functional cDNA clones of the human respiratory syncytial (RS) virus N, $\mathrm{P}$, and L proteins support replication of RS virus genomic RNA analogs and define minimal trans-acting requirements for RNA replication. J. Virol. 1995, 69, 2412-2419. [CrossRef] [PubMed]

129. Grosfeld, H.; Hill, M.G.; Collins, P.L. RNA replication by respiratory syncytial virus (RSV) is directed by the $\mathrm{N}, \mathrm{P}$, and L proteins; transcription also occurs under these conditions but requires RSV superinfection for efficient synthesis of full-length mRNA. J. Virol. 1995, 69, 5677-5686. [CrossRef]

130. Biacchesi, S.; Skiadopoulos, M.H.; Tran, K.C.; Murphy, B.R.; Collins, P.L.; Buchholz, U.J. Recovery of human metapneumovirus from cDNA: Optimization of growth in vitro and expression of additional genes. Virology 2004, 321, 247-259. [CrossRef]

131. Noton, S.L.; Fearns, R. Initiation and regulation of paramyxovirus transcription and replication. Virology 2015, 479-480, 545-554. [CrossRef]

132. Ruigrok, R.W.; Crépin, T.; Kolakofsky, D. Nucleoproteins and nucleocapsids of negative-strand RNA viruses. Curr. Opin. Microbiol. 2011, 14, 504-510. [CrossRef]

133. Kumar, S.; Nayak, B.; Collins, P.L.; Samal, S.K. Complete genome sequence of avian paramyxovirus type 3 reveals an unusually long trailer region. Virus Res. 2008, 137, 189-197. [CrossRef]

134. Kolakofsky, D.; Pelet, T.; Garcin, D.; Hausmann, S.; Curran, J.; Roux, L. Paramyxovirus RNA Synthesis and the Requirement for Hexamer Genome Length: The Rule of Six Revisited. J. Virol. 1998, 72, 891-899. [CrossRef] 
135. Alayyoubi, M.; Leser, G.P.; Kors, C.A.; Lamb, R.A. Structure of the paramyxovirus parainfluenza virus 5 nucleoprotein-RNA complex. Proc. Natl. Acad. Sci. USA 2015, 112, E1792-E1799. [CrossRef]

136. Calain, P.; Roux, L. The rule of six, a basic feature for efficient replication of Sendai virus defective interfering RNA. J. Virol. 1993, 67, 4822-4830. [CrossRef]

137. Durbin, A.P.; Siew, J.W.; Murphy, B.R.; Collins, P.L. Minimum protein requirements for transcription and RNA replication of a minigenome of human parainfluenza virus type 3 and evaluation of the rule of six. Virology 1997, 234, 74-83. [CrossRef]

138. Murphy, S.K.; Parks, G.D. Genome nucleotide lengths that are divisible by six are not essential but enhance replication of defective interfering RNAs of the paramyxovirus simian virus 5. Virology 1997, 232, 145-157. [CrossRef]

139. Marcos, F.; Ferreira, L.; Cros, J.; Park, M.-S.; Nakaya, T.; García-Sastre, A.; Villar, E. Mapping of the RNA promoter of Newcastle disease virus. Virology 2005, 331, 396-406. [CrossRef]

140. Samal, S.K.; Collins, P.L. RNA Replication by a Respiratory Syncytial Virus RNA Analog Does Not Obey the Rule of Six and Retains a Nonviral Trinucleotide Extension at the Leader End. J. Virol. 1996, 70, 8. [CrossRef]

141. Bhella, D.; Ralph, A.; Murphy, L.B.; Yeo, R.P. Significant differences in nucleocapsid morphology within the Paramyxoviridae. J. Gen. Virol. 2002, 83, 1831-1839. [CrossRef]

142. Kato, A.; Kiyotani, K.; Hasan, M.K.; Shioda, T.; Sakai, Y.; Yoshida, T.; Nagai, Y. Sendai virus gene start signals are not equivalent in reinitiation capacity: Moderation at the fusion protein gene. J. Virol. 1999, 73, 9237-9246. [CrossRef]

143. He, B.; Paterson, R.G.; Ward, C.D.; Lamb, R.A. Recovery of infectious SV5 from cloned DNA and expression of a foreign gene. Virology 1997, 237, 249-260. [CrossRef]

144. Wignall-Fleming, E.B.; Hughes, D.J.; Vattipally, S.; Modha, S.; Goodbourn, S.; Davison, A.J.; Randall, R.E. Analysis of Paramyxovirus Transcription and Replication by High-Throughput Sequencing. J. Virol. 2019, 93. [CrossRef]

145. Mackow, N.; Amaro-Carambot, E.; Liang, B.; Surman, S.; Lingemann, M.; Yang, L.; Collins, P.L.; Munir, S. Attenuated Human Parainfluenza Virus Type 1 (HPIV1) Expressing the Fusion Glycoprotein of Human Respiratory Syncytial Virus (RSV) as a Bivalent HPIV1/RSV Vaccine. J. Virol 2015, 89, 10319-10332. [CrossRef]

146. Liang, B.; Munir, S.; Amaro-Carambot, E.; Surman, S.; Mackow, N.; Yang, L.; Buchholz, U.J.; Collins, P.L.; Schaap-Nutt, A. Chimeric Bovine/Human Parainfluenza Virus Type 3 Expressing Respiratory Syncytial Virus (RSV) F Glycoprotein: Effect of Insert Position on Expression, Replication, Immunogenicity, Stability, and Protection against RSV Infection. J. Virol. 2014, 88, 4237-4250. [CrossRef]

147. Tang, R.S.; Schickli, J.H.; MacPhail, M.; Fernandes, F.; Bicha, L.; Spaete, J.; Fouchier, R.A.M.; Osterhaus, A.D.M.E.; Spaete, R.; Haller, A.A. Effects of Human Metapneumovirus and Respiratory Syncytial Virus Antigen Insertion in Two 3' Proximal Genome Positions of Bovine/Human Parainfluenza Virus Type 3 on Virus Replication and Immunogenicity. J. Virol. 2003, 77, 10819-10828. [CrossRef]

148. Zhao, H. Recombinant Newcastle disease virus as a viral vector: Effect of genomic location of foreign gene on gene expression and virus replication. J. Gen. Virol. 2003, 84, 781-788. [CrossRef]

149. Carnero, E.; Li, W.; Borderia, A.V.; Moltedo, B.; Moran, T.; Garcia-Sastre, A. Optimization of Human Immunodeficiency Virus Gag Expression by Newcastle Disease Virus Vectors for the Induction of Potent Immune Responses. J. Virol. 2009, 83, 584-597. [CrossRef]

150. Yoshida, A.; Samal, S.K. Avian Paramyxovirus Type-3 as a Vaccine Vector: Identification of a Genome Location for High Level Expression of a Foreign Gene. Front. Microbiol. 2017, 8, 693. [CrossRef]

151. Jones, B.G.; Sealy, R.E.; Rudraraju, R.; Traina-Dorge, V.L.; Finneyfrock, B.; Cook, A.; Takimoto, T.; Portner, A.; Hurwitz, J.L. Sendai virus-based RSV vaccine protects African green monkeys from RSV infection. Vaccine 2012, 30, 959-968. [CrossRef]

152. Zhan, X.; Hurwitz, J.L.; Krishnamurthy, S.; Takimoto, T.; Boyd, K.; Scroggs, R.A.; Surman, S.; Portner, A.; Slobod, K.S. Respiratory syncytial virus (RSV) fusion protein expressed by recombinant Sendai virus elicits B-cell and T-cell responses in cotton rats and confers protection against RSV subtypes A and B. Vaccine 2007, 25, 8782-8793. [CrossRef]

153. Russell, C.J.; Jones, B.G.; Sealy, R.E.; Surman, S.L.; Mason, J.N.; Hayden, R.T.; Tripp, R.A.; Takimoto, T.; Hurwitz, J.L. A Sendai virus recombinant vaccine expressing a gene for truncated human metapneumovirus (hMPV) fusion protein protects cotton rats from hMPV challenge. Virology 2017, 509, 60-66. [CrossRef] 
154. Skiadopoulos, M.H.; Surman, S.R.; Durbin, A.P.; Collins, P.L.; Murphy, B.R. Long Nucleotide Insertions between the HN and L Protein Coding Regions of Human Parainfluenza Virus Type 3 Yield Viruses With Temperature-Sensitive and Attenuation Phenotypes. Virology 2000, 272, 225-234. [CrossRef]

155. Liu, X.; Liang, B.; Ngwuta, J.; Liu, X.; Surman, S.; Lingemann, M.; Kwong, P.D.; Graham, B.S.; Collins, P.L.; Munir, S. Attenuated Human Parainfluenza Virus Type 1 Expressing the Respiratory Syncytial Virus (RSV) Fusion (F) Glycoprotein from an Added Gene: Effects of Prefusion Stabilization and Packaging of RSV F. J. Virol. 2017, 91, e01101-17. [CrossRef]

156. Schmidt, A.C.; McAuliffe, J.M.; Huang, A.; Surman, S.R.; Bailly, J.E.; Elkins, W.R.; Collins, P.L.; Murphy, B.R.; Skiadopoulos, M.H. Bovine parainfluenza virus type 3 (BPIV3) fusion and hemagglutinin-neuraminidase glycoproteins make an important contribution to the restricted replication of BPIV3 in primates. J. Virol. 2000, 74, 8922-8929. [CrossRef]

157. Karron, R.A.; Thumar, B.; Schappell, E.; Surman, S.; Murphy, B.R.; Collins, P.L.; Schmidt, A.C. Evaluation of two chimeric bovine-human parainfluenza virus type 3 vaccines in infants and young children. Vaccine 2012, 30, 3975-3981. [CrossRef]

158. Tang, R.S.; Spaete, R.R.; Thompson, M.W.; MacPhail, M.; Guzzetta, J.M.; Ryan, P.C.; Reisinger, K.; Chandler, P.; Hilty, M.; Walker, R.E.; et al. Development of a PIV-vectored RSV vaccine: Preclinical evaluation of safety, toxicity, and enhanced disease and initial clinical testing in healthy adults. Vaccine 2008, 26, 6373-6382. [CrossRef]

159. Gomez, M.; Mufson, M.A.; Dubovsky, F.; Knightly, C.; Zeng, W.; Losonsky, G. Phase-I study MEDI-534, of a live, attenuated intranasal vaccine against respiratory syncytial virus and parainfluenza-3 virus in seropositive children. Pediatr. Infect. Dis. J. 2009, 28, 655-658. [CrossRef]

160. Bernstein, D.I.; Malkin, E.; Abughali, N.; Falloon, J.; Yi, T.; Dubovsky, F. Phase 1 Study of the Safety and Immunogenicity of a Live, Attenuated Respiratory Syncytial Virus and Parainfluenza Virus Type 3 Vaccine in Seronegative Children. Pediatric Infect. Dis. J. 2012, 31, 109-114. [CrossRef]

161. Haller, A.A. Bovine parainfluenza virus type 3 (PIV3) expressing the respiratory syncytial virus (RSV) attachment and fusion proteins protects hamsters from challenge with human PIV3 and RSV. J. Gen. Virol. 2003, 84, 2153-2162. [CrossRef]

162. van Wyke Coelingh, K.L.; Winter, C.C.; Tierney, E.L.; London, W.T.; Murphy, B.R. Attenuation of bovine parainfluenza virus type 3 in nonhuman primates and its ability to confer immunity to human parainfluenza virus type 3 challenge. J. Infect. Dis. 1988, 157, 655-662. [CrossRef]

163. Belshe, R.B.; Karron, R.A.; Newman, F.K.; Anderson, E.L.; Nugent, S.L.; Steinhoff, M.; Clements, M.L.; Wilson, M.H.; Hall, S.L.; Tierney, E.L. Evaluation of a live attenuated, cold-adapted parainfluenza virus type 3 vaccine in children. J. Clin. Microbiol. 1992, 30, 2064-2070. [CrossRef]

164. Weinberg, G.A.; Hall, C.B.; Iwane, M.K.; Poehling, K.A.; Edwards, K.M.; Griffin, M.R.; Staat, M.A.; Curns, A.T.; Erdman, D.D.; Szilagyi, P.G. Parainfluenza Virus Infection of Young Children: Estimates of the Population-Based Burden of Hospitalization. J. Pediatrics 2009, 154, 694-699.e1. [CrossRef]

165. Bartlett, E.J.; Castaño, A.; Surman, S.R.; Collins, P.L.; Skiadopoulos, M.H.; Murphy, B.R. Attenuation and efficacy of human parainfluenza virus type 1 (HPIV1) vaccine candidates containing stabilized mutations in the $\mathrm{P} / \mathrm{C}$ and L genes. Virol. J. 2007, 4, 67. [CrossRef]

166. Karron, R.A.; San Mateo, J.; Thumar, B.; Schaap-Nutt, A.; Buchholz, U.J.; Schmidt, A.C.; Bartlett, E.J.; Murphy, B.R.; Collins, P.L. Evaluation of a Live-Attenuated Human Parainfluenza Type 1 Vaccine in Adults and Children. J. Pediatric Infect. Dis. Soc. 2015, 4, e143-e146. [CrossRef]

167. Sealy, R.; Jones, B.G.; Surman, S.L.; Hurwitz, J.L. Robust IgA and IgG-producing antibody forming cells in the diffuse-NALT and lungs of Sendai virus-vaccinated cotton rats associate with rapid protection against human parainfluenza virus-type 1 . Vaccine 2010, 28, 6749-6756. [CrossRef]

168. Hurwitz, J.L.; Soike, K.F.; Sangster, M.Y.; Portner, A.; Sealy, R.E.; Dawson, D.H.; Coleclough, C. Intranasal Sendai virus vaccine protects African green monkeys from infection with human parainfluenza virus-type one. Vaccine 1997, 15, 533-540. [CrossRef]

169. Slobod, K.S.; Shenep, J.L.; Luján-Zilbermann, J.; Allison, K.; Brown, B.; Scroggs, R.A.; Portner, A.; Coleclough, C.; Hurwitz, J.L. Safety and immunogenicity of intranasal murine parainfluenza virus type 1 (Sendai virus) in healthy human adults. Vaccine 2004, 22, 3182-3186. [CrossRef] 
170. Adderson, E.; Branum, K.; Sealy, R.E.; Jones, B.G.; Surman, S.L.; Penkert, R.; Freiden, P.; Slobod, K.S.; Gaur, A.H.; Hayden, R.T.; et al. Safety and immunogenicity of an intranasal Sendai virus-based human parainfluenza virus type 1 vaccine in 3- to 6-year-old children. Clin. Vaccine Immunol. 2015, 22, 298-303. [CrossRef]

171. Vulliemoz, D.; Roux, L. "Rule of Six": How Does the Sendai Virus RNA Polymerase Keep Count? J. Virol. 2001, 75, 4506-4518. [CrossRef]

172. Sakai, Y.; Kiyotani, K.; Fukumura, M.; Asakawa, M.; Kato, A.; Shioda, T.; Yoshida, T.; Tanaka, A.; Hasegawa, M.; Nagai, Y. Accommodation of foreign genes into the Sendai virus genome: Sizes of inserted genes and viral replication. FEBS Lett. 1999, 456, 221-226. [CrossRef]

173. Takimoto, T.; Hurwitz, J.L.; Coleclough, C.; Prouser, C.; Krishnamurthy, S.; Zhan, X.; Boyd, K.; Scroggs, R.A.; Brown, B.; Nagai, Y.; et al. Recombinant Sendai Virus Expressing the G Glycoprotein of Respiratory Syncytial Virus (RSV) Elicits Immune Protection against RSV. J. Virol. 2004, 78, 6043-6047. [CrossRef]

174. Jones, B.G.; Sealy, R.E.; Surman, S.L.; Portner, A.; Russell, C.J.; Slobod, K.S.; Dormitzer, P.R.; DeVincenzo, J.; Hurwitz, J.L. Sendai virus-based RSV vaccine protects against RSV challenge in an in vivo maternal antibody model. Vaccine 2014, 32, 3264-3273. [CrossRef]

175. Zhan, X.; Slobod, K.S.; Jones, B.G.; Sealy, R.E.; Takimoto, T.; Boyd, K.; Surman, S.; Russell, C.J.; Portner, A.; Hurwitz, J.L. Sendai virus recombinant vaccine expressing a secreted, unconstrained respiratory syncytial virus fusion protein protects against RSV in cotton rats. Int. Immunol. 2015, 27, 229-236. [CrossRef]

176. Zhan, X.; Slobod, K.S.; Krishnamurthy, S.; Luque, L.E.; Takimoto, T.; Jones, B.; Surman, S.; Russell, C.J.; Portner, A.; Hurwitz, J.L. Sendai virus recombinant vaccine expressing hPIV-3 HN or F elicits protective immunity and combines with a second recombinant to prevent hPIV-1, hPIV-3 and RSV infections. Vaccine 2008, 26, 3480-3488. [CrossRef]

177. Jones, B.; Zhan, X.; Mishin, V.; Slobod, K.S.; Surman, S.; Russell, C.J.; Portner, A.; Hurwitz, J.L. Human PIV-2 recombinant Sendai virus ( $\mathrm{rSeV}$ ) elicits durable immunity and combines with two additional rSeVs to protect against hPIV-1, hPIV-2, hPIV-3, and RSV. Vaccine 2009, 27, 1848-1857. [CrossRef]

178. Lippmann, O. Human conjunctivitis due to the Newcastle-disease virus of fowls. Am. J. Ophthalmol. 1952, 35, 1021-1028. [CrossRef]

179. Nelson, C.B.; Pomeroy, B.S.; Schrall, K.; Park, W.E.; Lindeman, R.J. An outbreak of conjunctivitis due to Newcastle disease virus (NDV) occurring in poultry workers. Am. J. Public Health Nations Health 1952, 42, 672-678. [CrossRef]

180. Samal, S.K. Newcastle disease and related avian paramyxoviruses. In The Biology of Paramyxoviruses; Caister Academic Press: Norfolk, UK, 2011; pp. 69-114.

181. Wilson, D.E.; Chosewood, L.C. Biosafety in Microbiological and Biomedical Laboratories, 5th ed.; U.S. Department of Health and Human Services: Washington, DC, USA, 2009.

182. Bukreyev, A.; Huang, Z.; Yang, L.; Elankumaran, S.; St Claire, M.; Murphy, B.R.; Samal, S.K.; Collins, P.L. Recombinant Newcastle Disease Virus Expressing a Foreign Viral Antigen Is Attenuated and Highly Immunogenic in Primates. J. Virol. 2005, 79, 13275-13284. [CrossRef]

183. Honda, K.; Sakaguchi, S.; Nakajima, C.; Watanabe, A.; Yanai, H.; Matsumoto, M.; Ohteki, T.; Kaisho, T.; Takaoka, A.; Akira, S.; et al. Selective contribution of IFN- / signaling to the maturation of dendritic cells induced by double-stranded RNA or viral infection. Proc. Natl. Acad. Sci. USA 2003, 100, 10872-10877. [CrossRef]

184. Kim, S.-H.; Samal, S. Newcastle Disease Virus as a Vaccine Vector for Development of Human and Veterinary Vaccines. Viruses 2016, 8, 183. [CrossRef]

185. Martinez-Sobrido, L.; Gitiban, N.; Fernandez-Sesma, A.; Cros, J.; Mertz, S.E.; Jewell, N.A.; Hammond, S.; Flano, E.; Durbin, R.K.; García-Sastre, A.; et al. Protection against respiratory syncytial virus by a recombinant Newcastle disease virus vector. J. Virol. 2006, 80, 1130-1139. [CrossRef]

186. DiNapoli, J.M.; Kotelkin, A.; Yang, L.; Elankumaran, S.; Murphy, B.R.; Samal, S.K.; Collins, P.L.; Bukreyev, A. Newcastle disease virus, a host range-restricted virus, as a vaccine vector for intranasal immunization against emerging pathogens. Proc. Natl. Acad. Sci. USA 2007, 104, 9788-9793. [CrossRef]

187. Hu, H.; Roth, J.P.; Estevez, C.N.; Zsak, L.; Liu, B.; Yu, Q. Generation and evaluation of a recombinant Newcastle disease virus expressing the glycoprotein $(\mathrm{G})$ of avian metapneumovirus subgroup $\mathrm{C}$ as a bivalent vaccine in turkeys. Vaccine 2011, 29, 8624-8633. [CrossRef] 
188. Yu, Q.; Roth, J.P.; Hu, H.; Estevez, C.N.; Zhao, W.; Zsak, L. Protection by Recombinant Newcastle Disease Viruses (NDV) Expressing the Glycoprotein (G) of Avian Metapneumovirus (aMPV) Subtype A or B against Challenge with Virulent NDV and aMPV. World J. Vaccines 2013, 03, 130-139. [CrossRef]

189. Hu, H.; Roth, J.P.; Zsak, L.; Yu, Q. Engineered Newcastle disease virus expressing the F and G proteins of AMPV-C confers protection against challenges in turkeys. Sci. Rep. 2017, 7, 4025. [CrossRef]

190. Khattar, S.K.; Manoharan, V.; Bhattarai, B.; LaBranche, C.C.; Montefiori, D.C.; Samal, S.K. Mucosal Immunization with Newcastle Disease Virus Vector Coexpressing HIV-1 Env and Gag Proteins Elicits Potent Serum, Mucosal, and Cellular Immune Responses That Protect against Vaccinia Virus Env and Gag Challenges. MBio 2015, 6, e01005. [CrossRef]

191. Khattar, S.K.; DeVico, A.L.; LaBranche, C.C.; Panda, A.; Montefiori, D.C.; Samal, S.K. Enhanced Immune Responses to HIV-1 Envelope Elicited by a Vaccine Regimen Consisting of Priming with Newcastle Disease Virus Expressing HIV gp160 and Boosting with gp120 and SOSIP gp140 Proteins. J. Virol. 2016, 90, 1682-1686. [CrossRef]

192. Xu, X.; Xue, C.; Liu, X.; Li, J.; Fei, Y.; Liu, Z.; Mu, J.; Bi, Y.; Qian, J.; Yin, R.; et al. A novel recombinant attenuated Newcastle disease virus expressing $\mathrm{H} 9$ subtype hemagglutinin protected chickens from challenge by genotype VII virulent Newcastle disease virus and H9N2 avian influenza virus. Vet. Microbiol. 2019, 228, 173-180. [CrossRef]

193. Kong, D.; Wen, Z.; Su, H.; Ge, J.; Chen, W.; Wang, X.; Wu, C.; Yang, C.; Chen, H.; Bu, Z. Newcastle disease virus-vectored Nipah encephalitis vaccines induce B and $\mathrm{T}$ cell responses in mice and long-lasting neutralizing antibodies in pigs. Virology 2012, 432, 327-335. [CrossRef]

194. Bukreyev, A.; Rollin, P.E.; Tate, M.K.; Yang, L.; Zaki, S.R.; Shieh, W.-J.; Murphy, B.R.; Collins, P.L.; Sanchez, A. Successful topical respiratory tract immunization of primates against Ebola virus. J. Virol. 2007, 81, 6379-6388. [CrossRef]

195. Schnell, M.J.; Buonocore, L.; Whitt, M.A.; Rose, J.K. The minimal conserved transcription stop-start signal promotes stable expression of a foreign gene in vesicular stomatitis virus. J. Virol. 1996, 70, 2318-2323. [CrossRef]

196. Pattnaik, A.K.; Wertz, G.W. Replication and amplification of defective interfering particle RNAs of vesicular stomatitis virus in cells expressing viral proteins from vectors containing cloned cDNAs. J. Virol. 1990, 64, 2948-2957. [CrossRef]

197. van den Pol, A.N.; Dalton, K.P.; Rose, J.K. Relative Neurotropism of a Recombinant Rhabdovirus Expressing a Green Fluorescent Envelope Glycoprotein. J. Virol. 2002, 76, 1309-1327. [CrossRef]

198. Johnson, J.E.; Nasar, F.; Coleman, J.W.; Price, R.E.; Javadian, A.; Draper, K.; Lee, M.; Reilly, P.A.; Clarke, D.K.; Hendry, R.M.; et al. Neurovirulence properties of recombinant vesicular stomatitis virus vectors in non-human primates. VirolOGY 2007, 360, 36-49. [CrossRef]

199. Roberts, A.; Buonocore, L.; Price, R.; Forman, J.; Rose, J.K. Attenuated vesicular stomatitis viruses as vaccine vectors. J. Virol. 1999, 73, 3723-3732. [CrossRef]

200. Forger, J.M.; Bronson, R.T.; Huang, A.S.; Reiss, C.S. Murine infection by vesicular stomatitis virus: Initial characterization of the H-2d system. J. Virol. 1991, 65, 4950-4958. [CrossRef]

201. Fellowes, O.N.; Dimopoullos, G.T.; Callis, J.J. Isolation of vesicular stomatitis virus from an infected laboratory worker. Am. J. Vet. Res. 1955, 16, 623-626.

202. Hanson, R.P.; Rasmussen, A.F.; Brandly, C.A.; Brown, J.W. Human infection with the virus of vesicular stomatitis. J. Lab. Clin. Med. 1950, 36, 754-758.

203. Johnson, K.M.; Peralta, P.H.; Vogel, J.E. Clinical and Serological Response to Laboratory-Acquired Human Infection by Indiana Type Vesicular Stomatitis Virus (VSV). Am. J. Trop. Med. Hyg. 1966, 15, 244-246. [CrossRef]

204. Moreno, N.; Quiroz, E.; Tesh, R.B.; Peralta, P.H. A Human Case of Encephalitis Associated with Vesicular Stomatitis Virus (Indiana Serotype) Infection. Am. J. Trop. Med. Hyg. 1988, 39, 312-314.

205. Wachtman, L.; Mansfield, K. Viral Diseases of Nonhuman Primates. In Nonhuman Primates in Biomedical Research; Abee, C., Mansfield, M., Tardif, S., Morris, T., Eds.; Elsevier: Amsterdam, The Netherlands, 2012; pp. 1-104. ISBN 978-0-12-381366-4.

206. Tober, R.; Banki, Z.; Egerer, L.; Muik, A.; Behmuller, S.; Kreppel, F.; Greczmiel, U.; Oxenius, A.; von Laer, D.; Kimpel, J. VSV-GP: A Potent Viral Vaccine Vector That Boosts the Immune Response upon Repeated Applications. J. Virol. 2014, 88, 4897-4907. [CrossRef] 
207. Wilmschen, S.; Schneider, S.; Peters, F.; Bayer, L.; Issmail, L.; Bánki, Z.; Grunwald, T.; von Laer, D.; Kimpel, J. RSV Vaccine Based on Rhabdoviral Vector Protects after Single Immunization. Vaccines 2019, 7, 59. [CrossRef] [PubMed]

208. Kahn, J.S.; Schnell, M.J.; Buonocore, L.; Rose, J.K. Recombinant Vesicular Stomatitis Virus Expressing Respiratory Syncytial Virus (RSV) Glycoproteins: RSV Fusion Protein Can Mediate Infection and Cell Fusion. Virology 1999, 254, 81-91. [CrossRef] [PubMed]

209. Kahn, J.S.; Roberts, A.; Weibel, C.; Buonocore, L.; Rose, J.K. Replication-Competent or Attenuated, Nonpropagating Vesicular Stomatitis Viruses Expressing Respiratory Syncytial Virus (RSV) Antigens Protect Mice against RSV Challenge. J. Virol. 2001, 75, 11079-11087. [CrossRef]

210. Johnson, J.E.; McNeil, L.K.; Megati, S.; Witko, S.E.; Roopchand, V.S.; Obregon, J.H.; Illenberger, D.M.; Kotash, C.S.; Nowak, R.M.; Braunstein, E.; et al. Non-propagating, recombinant vesicular stomatitis virus vectors encoding respiratory syncytial virus proteins generate potent humoral and cellular immunity against RSV and are protective in mice. Immunol. Lett. 2013, 150, 134-144. [CrossRef] [PubMed]

211. van den Hoogen, B.G.; Bestebroer, T.M.; Osterhaus, A.D.M.E.; Fouchier, R.A.M. Analysis of the Genomic Sequence of a Human Metapneumovirus. Virology 2002, 295, 119-132. [CrossRef] [PubMed]

212. Johnson, J.E.; Schnell, M.J.; Buonocore, L.; Rose, J.K. Specific targeting to CD4+ cells of recombinant vesicular stomatitis viruses encoding human immunodeficiency virus envelope proteins. J. Virol. 1997, 71, 5060-5068. [CrossRef] [PubMed]

213. Bresk, C.; Hofer, T.; Wilmschen, S.; Krismer, M.; Beierfuß, A.; Effantin, G.; Weissenhorn, W.; Hogan, M.; Jordan, A.; Gelman, R.; et al. Induction of Tier 1 HIV Neutralizing Antibodies by Envelope Trimers Incorporated into a Replication Competent Vesicular Stomatitis Virus Vector. Viruses 2019, 11, 159. [CrossRef] [PubMed]

(C) 2020 by the authors. Licensee MDPI, Basel, Switzerland. This article is an open access article distributed under the terms and conditions of the Creative Commons Attribution (CC BY) license (http://creativecommons.org/licenses/by/4.0/). 